\title{
Review of Survey Data on the Importance of Energy Efficiency to New Home Buyers
}

\author{
P. L. Hendrickson
}

October 1984

Prepared for the Office of Conservation Bonneville Power Administration under a Related Services Agreement with the U.S. Department of Energy under Contract DE-AC06-76RLO 1830

Pacific Northwest Laboratory Operated for the U.S. Department of Energy by Battelle Memorial Institute 


\title{
DISCLAIMER
}

This report was prepared as an account of work sponsored by an agency of the United States Government. Neither the United States Government nor any agency thereof, nor any of their employees, makes any warranty, express or implied, or assumes any legal liability or responsibility for the accuracy, completeness, or usefulness of any information, apparatus, product, or process disclosed, or represents that its use would not infringe privately owned rights. Reference herein to any specific commercial product, process, or service by trade name, trademark, manufacturer, or otherwise, does not necessarily constitute or imply its endorsement, recommendation, or favoring by the United States Government or any agency thereof. The views and opinions of authors expressed herein do not necessarily state or reflect those of the United States Government or any agency thereof.

\author{
PACIFIC NORTHWEST LABORATORY \\ operated by \\ BATTELLE \\ for the \\ UNITED STATES DEPARTMENT OF ENERGY \\ under Contract DE-AC06-76RLO 1830
}

\begin{tabular}{|c|c|}
\hline \multirow{2}{*}{\multicolumn{2}{|c|}{ Printed in the United States of America }} \\
\hline & \\
\hline \multicolumn{2}{|c|}{ Available from } \\
\hline \multicolumn{2}{|c|}{$\begin{array}{l}\text { National Technical Information Service } \\
\text { United States Department of Commerce }\end{array}$} \\
\hline \multicolumn{2}{|c|}{5285 Port Royal Road } \\
\hline \multicolumn{2}{|c|}{ Springfield, Virginia 22161} \\
\hline \multirow{2}{*}{\multicolumn{2}{|c|}{$\begin{array}{l}\text { NTIS Price Codes } \\
\text { Microfiche } A 01\end{array}$}} \\
\hline & \\
\hline \multicolumn{2}{|c|}{ Printed Copy } \\
\hline Pages & $\begin{array}{l}\text { Price } \\
\text { Codes }\end{array}$ \\
\hline 007-025 & A02 \\
\hline 026-050 & $\mathrm{A} 03$ \\
\hline 051-075 & A04 \\
\hline 076-100 & A05 \\
\hline $101-125$ & A06 \\
\hline $126-150$ & A07 \\
\hline $151-175$ & $A 08$ \\
\hline $176-200$ & A09 \\
\hline $201-225$ & $\mathrm{~A} 010$ \\
\hline $226-250$ & A011 \\
\hline $251-275$ & A012 \\
\hline $276-300$ & A013 \\
\hline
\end{tabular}




\section{9}

PNL -5297

UC $-95 d$

REVIEW OF SURVEY DATA ON THE IMPORTANCE OF ENERGY EFFICIENCY TO NEH HOME BUYERS

P. L. Hendrickson

October 1984

Prepared for the Office of Conservation

Bonneville Power Administration

under a Related Services Agreement with

the U.S. Department of Energy

under Contract DE-AC06-76RLO 1830

Pacific Northwest Laboratory

Richland, Washington 99352 
4

.

. 
SUMMARY

The principal objective of this report was to review available survey information on the importance of energy efficiency to buyers of newly constructed homes. The importance of energy efficiency to buyers of existing homes was of secondary importance. Highlights of documents reviewed for the study are included in the appendix. A companion report to this document prepared by the Portland, Oregon, fim of Bardsley and Haslacher, Inc., reviews the results of six focus groups convened in the Northwest to obtain energy efficiency preference information from recent buyers of newly constructed homes.

The report was prepared for the Office of Conservation, Bonneville Power Administration (BPA). The information will be used by BPA to encourage implementation of the model conservation standards adopted by the Northwest Power Planning Council and to facilitate marketing of demonstration homes built to the standards. It will also be used to aid in marketing the "Super Good Cents" program, a program that will be operated by utilities. New homes built to the model standards will be certified and marketed as "Super Good Cents" homes.

Overall, the surveys reviewed for this report support the notion that the Council's model conservation standards will be received reasonably well and can be successfully marketed. The standards principally affect new building construction. Survey results show that prospective buyers of newly constructed homes are highly interested in energy efficiency.

A number of subtopics are addressed in the report. These include the home purchase process and the role of energy efficiency considerations in the process, the importance of energy efficiency considerations in the decision to purchase a new home, the relative importance of energy efficiency in comparison to other home selection attributes, homeowner preferences for particular energy efficiency features, and measures of the willingness to pay for energy efficiency improvements. 
CONTENTS

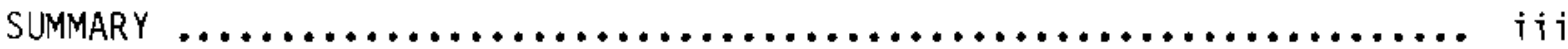

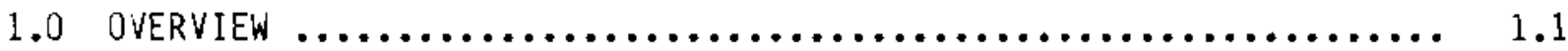

2.0 INTRODUCTION $\ldots \ldots \ldots \ldots \ldots \ldots \ldots \ldots \ldots \ldots \ldots \ldots \ldots \ldots \ldots \ldots, 2.1$

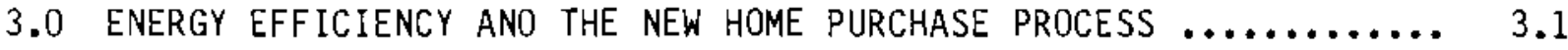

3.1 SELECTION ATTRIBUTES AND THE DECISION PROCESS $\ldots \ldots \ldots \ldots \ldots . .1$

3.2 RISK FACTDRS IN THE PURCHASE PROCESS $\ldots \ldots \ldots \ldots \ldots \ldots \ldots \ldots . .2$

3.2.1 Soecial Risks Associated with Energy
Efficient Homes $\ldots \ldots \ldots \ldots \ldots \ldots \ldots \ldots \ldots \ldots \ldots \ldots \ldots \ldots \ldots \ldots . .$.

3.2 .2 Financial Risks $\ldots \ldots \ldots \ldots \ldots \ldots \ldots \ldots \ldots \ldots \ldots \ldots, 3.3$

3.3 IMPACT OF ENERGY EFFICIENCY ON HOME FINANCING $\ldots \ldots \ldots \ldots \ldots . .3 .4$

3.4 NEWLYY CONSTRUCTED VERSUS EXISTING HOMES $\ldots \ldots \ldots \ldots \ldots \ldots \ldots . . .5$

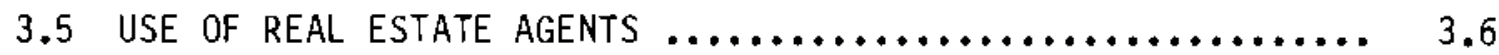

3.6 HUSBAND-WIFE INTERACTIONS $\ldots \ldots \ldots \ldots \ldots \ldots \ldots \ldots \ldots \ldots \ldots \ldots \ldots \ldots \ldots . .7$

3.7 SOURCES OF ENERGY EFFICIENCY INFORMATION $\ldots \ldots \ldots \ldots \ldots \ldots \ldots . . . .6$

4.0 ROLE OF ENERGY EFFICIENCY IN DECISIONS TO SEEK AND SELECT

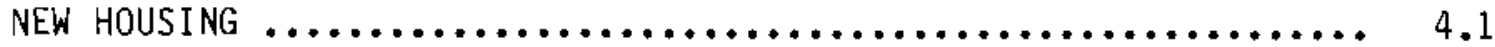

4.1 RELATIVE IMPORTANCE OF REASONS TO SEEK NEW HOUSING $\ldots \ldots \ldots . .4 .1$

4.2 RELATIVE IMPORTANCE OF PARTICULAR AJTRIBUTES IN
HOME SELECTION $\ldots \ldots \ldots \ldots \ldots \ldots \ldots \ldots \ldots \ldots \ldots \ldots \ldots \ldots \ldots \ldots \ldots \ldots \ldots \ldots$

5.0 IMPORTANCE OF PARTICULAR ENERGY EFF ICIENCY
FEATURES AND WILLINGNESS TD PAY FOR THEM $\ldots \ldots \ldots \ldots \ldots \ldots \ldots \ldots$.

5.1 RELATIVE IMPORTANCE OF PARTICULAR ENERGY

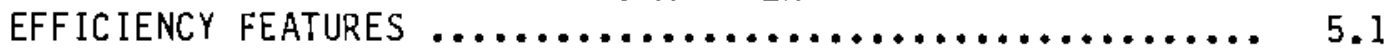

5.2 WILLINGNESS TO PAY FOR ENERGY EFFICIENCY IMPROVEMENTS $\ldots \ldots .5 .2$

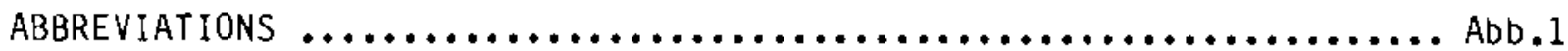

APPENDIX: HIGHLIGHTS OF SURVEYS AND DOCUMENTS REVIEWED

FOR THE REPORT $\ldots \ldots \ldots \ldots \ldots \ldots \ldots \ldots \ldots \ldots \ldots \ldots \ldots \ldots \ldots \ldots \ldots \ldots$, A.1 
1. National Consumer/Builder Survey an Housing,

Professional Builder Magazine ..................... A.1

2. What Buyers Want: A 1984 Survey of Prospective New Home Buyers, Builder Magazine .................... A.4

3. Surveys in Support of the Residential Energy Evaluation Program, Wehbring and Lavis ............. A.6

4. Decisions for the 1980s, National Association of Home Builders .................................. A.11

5. Fourth Annual Home-Shopper Survey: Buyer Preferences

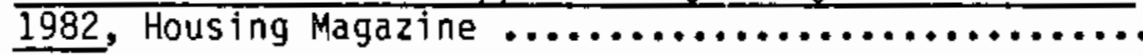

6. National Homebuying Survey, National Association

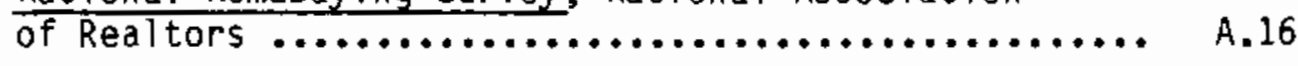

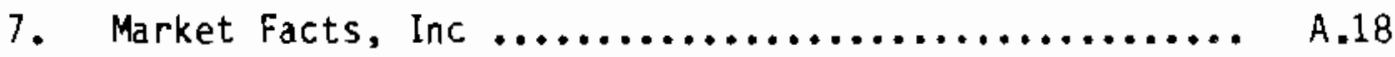

7A. Study of Potential Home Buyers...$\ldots \ldots \ldots \ldots \ldots \ldots$........... A

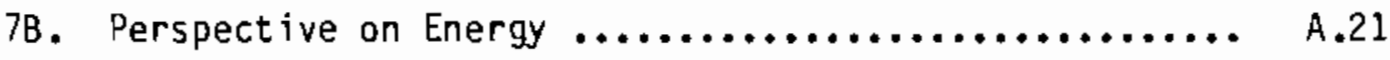

7C. Professional Builder's 1980 Consumer/Builder Survey on Housing ................................... A.23

8. Energy and Housing: Consumer and Builder Perspectives, University of North Carolina at Chapel HilT .......... A.25

9. Building and Occupant Characteristics as Determinants of Residential Energy Consumption, Pacific Northwest

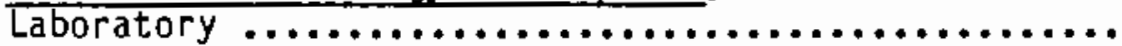

10. The Home Purchase Process: Measurement of Evaluative Criteria Through Pairwise Measures, Freiden and

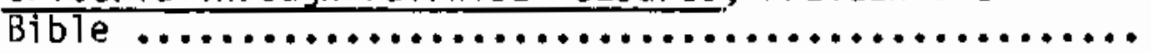

11. Joint Decisions in Home Purchasing: A Muddling Through Process, Park

12. A Study of Joint Decision Making Between Husbands and Wives in a Housing Purchase Decision, Qualls .........

13. The Use of Home Energy Audits and Home Energy Rating Systems in the Home Selection Process, Decision Research Corp. ................................

14. Conservation Characteristics Among Determinants of Residential Property Value, Longstreth 
15. Tenant-Paid Energy Costs in Multifamily Rental Housing: Effects on Energy Use, Owner Investment, and Market Value of Energy, McClelland ................. A.37

16. Final Report on the Class $C$ Passive Performance Evaluation Program, Mid-American Solar Energy Complex .................................. A.38 
$\underline{\text { TABLES }}$

1.1 National Average Retail Residential Fuel Prices Delivered by

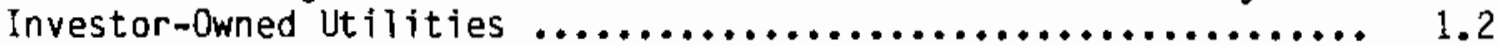

3.1 Percent of New Loans with an Adjustable Interest Rate....... .3 .4$

4.1 Relative Importance of Selection Attributes to Individuals who had Purchased a New Home $\ldots . . . . . . . . . . . . . . .4 .4$

5.1 Willingness to Spend on Energy Efficiency Improvements $\ldots . \ldots \ldots .2$

A.1 What Consumers Seek in the Purchase of a Home $\ldots \ldots \ldots \ldots \ldots \ldots . . .12$

A.2 Willingness of Homeowners to Add Energy-Saving Features to Their Homes and the Types of Heating System under Consideration $. . \ldots \ldots \ldots \ldots \ldots \ldots \ldots \ldots \ldots \ldots \ldots \ldots \ldots \ldots . . .14$

A.3 Prospective Home Buyers' Interest in

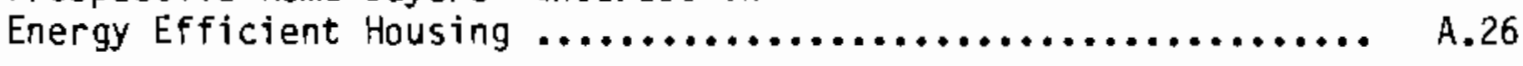

A.4 Types of Households Most Likely to Demand Energy Efficient New Homes $\ldots \ldots \ldots \ldots \ldots \ldots \ldots \ldots \ldots \ldots \ldots$. A.27

A.5 Couple's Relative Influence Responses $\ldots \ldots \ldots \ldots \ldots \ldots \ldots \ldots \ldots$ A.33 


\subsection{OVERVIEW}

The principal objective of this report was to review available survey information on the importance of energy efficiency to buyers of newly constructed homes. The importance of energy efficiency to buyers of existing homes was of secondary importance. Sixteen documents were reviewed for the study. Highlights from these studies are included in Appendix A. The reports are arranged in approximate order of significance to the study. A companion report to this document prepared by the firm of Bardsley and Haslacher, Inc., reviews the results of six focus groups held in the Northwest to obtain information on the sane subjects. (1)

The report was prepared for the Office of Conservation, Bonneville Power Administration (BPA). The information will be used by BPA in encouraging implementation of the model conservation standards adopted by the Northwest Power Planning Council and in facilitating the marketing of demonstration homes built to the standards. It will also be used to aid in marketing the "Super Good Cents" program, a program that will be operated by utilities. New homes built to the model standards will be certified and marketed as "Super Good Cents" homes.

A number of subtopics are addressed in the report. These include the home purchase process and the role of energy efficiency considerations in the process, the importance of energy efficiency considerations in the decision to purchase a new home, the relative importance of energy efficiency in comparison to other home selection attributes, homeowner preferences for particular energy efficiency features, and measures of the willingness to pay for energy efficiency improvements.

Energy efficiency considerations affect the home purchase process in several important ways. Theory suggests that other things being equal, an energy efficient home should sell for more than an inefficient home. Empirical studies (e.g., p. A.36) confirm this expectation. For buyers who are at a financial institution's debt margin, there is a possibility of borrowing additional funds for an energy efficient home beyond normal Toan/income guidelines because of lower expected utility costs. Buyers also perceive certain risks 
associated with the extra costs of purchasing an energy efficient home. These risks relate to the possible use of new, unproven technology and installation/ construction by contractors and builders who are still learning how to construct energy efficient homes. At the same time, buyers recognize that it is more efficient to initially construct an energy efficient home than to retrofit an existing home with energy saving features. When couples are purchasing a home, there is evidence that husbands exert the greatest influence over the energy efficiency attribute of the selection process.

A complicating factor in assessing the relative importance of energy efficiency to home buyers is that the importance is impacted by a number of variables that are difficult to account for. These variables include household income, the relative severity of the local climate, and expectations of future energy price increases. For example, a high-incone household living in a temperate climate is likeiy to weight efficiency lower as a selection attribute than a medium-income household in a severe climate. The available literature rarely examines the correlation between energy efficiency survey data and these variables, and consequently no attempt is made to do so in this report.

The reader can make some assessment of the impact of rising energy prices by noting when a particular survey was taken. The surveys reviewed for this report were taken during the period 1977-1983. National average residential natural gas and electricity prices for this period are shown in Table 1.1. TABLE 1.1. National Average Retail Residential Fulel Prices Delivered by

\begin{tabular}{|c|c|c|c|c|}
\hline Year & $\begin{array}{l}\text { Electricity } \\
\text { (cents/kWhr) }\end{array}$ & $\begin{array}{l}\% \text { Increase from } \\
\text { Previous Year }\end{array}$ & $\begin{array}{l}\text { Natural Gas (dollars/ } \\
\text { thousand cu. ft) }\end{array}$ & $\begin{array}{l}\text { \$ Increase from } \\
\text { Previous Year }\end{array}$ \\
\hline 1977 & $4.05 \phi$ & $8.6 \%$ & $\$ 2.35$ & $18.7 \%$ \\
\hline 1978 & 4.31 & 6.4 & 2.56 & 8.9 \\
\hline 1979 & 4.64 & 7.7 & 2.98 & 16.4 \\
\hline 1980 & 5.36 & 15.5 & 3.68 & 23.5 \\
\hline 1981 & 6.20 & 15.7 & 4.29 & 16.6 \\
\hline 1982 & 6.86 & 10.6 & 5.17 & 20.5 \\
\hline 1983 & 7.18 & 4.7 & 5.99 & 15.9 \\
\hline
\end{tabular}


One would expect, for example, that the relative importance of energy efficiency to home buyers nationally, other factors being equal, might be greater in 1980-1981 when both electricity and natural gas prices were rapidly increasing than in 1983 when price increases, especially for electricity, were moderating. Evidence to support this hypothesis includes a decreasing percentage of potential buyers of newly constructed homes who are willing to spend $\$ 1000$ initially to save $\$ 100 / y r$ on fuel costs (see below). An NAHB official also cites a "lu11 in interest in increasing energy efficiency among both builders and consumers," and a greater emphasis on affordability. (3)

The survey data on reasons to buy a different home suggest an interesting distinction. Individuals who are principally in the market for a newly constructed home apparently place much greater emphasis on improved energy efficiency as a reason to buy than do prospective buyers in general. Prospective buyers of newly constructed homes appear to rank improved energy efficiency as high or higher than any other reason to buy. Prospective buyers of homes in general cite other reasons, such as more room or a preferred location, as more important.

As one would expect, the survey data on the relative importance of energy efficiency as a home selection attribute are not completely consistent, but they do suggest that energy efficiency follows price, location, home size, Jesign/style, and construction quality in importance. There is some evidence that its relative importance may be increasing. A 1980 survey by the National Association of Home Builders (p. A.13) of individuals who bought newly constructed homes in 1977 and 1978 found that the buyers would place much greater emphasis on energy efficiency when purchasing their next home.

Survey data suggest that the most important energy efficiency features in decreasing order of importance are insulation (with ceiling most important followed by wall and floor), extra window glazing, and appropriate weatherstripjing and caulking.

Approximately $64 \%$ of respondents to one 1983 survey (p. A.1) would be willing to spend an additional $\$ 1000$ for a new home with energy efficiency 
features that would save them $\$ 100 / y r$. This percentage had dropped from $78 \%$ in 1981, suggesting a possible moderating interest in energy efficiency.

Overa 11, the surveys reviewed for this report support the notion that the Northwest Power Planning Council's model conservation standards will be received reasonably well and can be successfully marketed. The standards principally affect new building construction. Survey results show that prospective buyers of newly constructed homes are highly interested in energy efficiency. Further evidence that buyers of newly constructed homes will support the standards is found in a report that surveyed the energy conservation attitudes and behavior of individuals living in western states. Approximately $80 \%$ of res $i-$ dents in Idaho, Montana, Oregon, and Washington supported the idea of stronger building codes to encourage energy saving housing. (4) Moreover, in a recent telephone survey of 603 0regon residents, $87 \%$ of respondents favored requiring new buildings to be energy efficient and $77 \%$ favored enforcement of energy efficient building codes. (5) 
1. Bardsley and Haslacher, Inc., Portland, Oregon, Northwest New Home Buyers Discuss the Home Purchase Decision, October 1984.

2. Energy Information Administration, U.S. Department of Energy. Monthly Energy Review, D0E/EIA-0035(84/01), pp. 93, 94, April 1984.

3. Builder, The Magazine of the National Association of Home Builders, Washington, D.C., p. 73, August, 1984.

4. Western Rural Development Center, Oregon State University, Energy Directions for the United States: A Western Perspective, WRDC Publication No. 13, August 1982, P. 21 .

5. H. M. Berg, P. K. Bodenroeder, Survey Research Center, Oregon State University, Attitudes, Opinions and Concerns About Energy - A Survey of Oregon Residents, prepared for the Oregon Department of Energy, TabTes $5.1,6.1$, May 1984. 
$\uparrow$

,

ง 


\subsection{INTRODUCTION}

This report is one in a series of reports on marketing energy conservation in the Northwest prepared by the Pacific Northwest Laboratory (PNL) and its subcontractors for the Office of Conservation, Bonneville Power Administration (BPA). Other reports are:

1. RMH Research, Inc., River Edge, New Jersey, Marketing Environment for Energy Conservation in the Pacific Northwest, May 1984.

2. RMH Research, Inc., Marketing Environment for Solar and Heat Pump Water Heaters, May 1984.

3. Bardsley and Haslacher, Inc., Portland, Oregon, Northwest New Home Buyers Discuss the Home Purchase Decision, October 1984.

4. J. M. Fang, Attitudes Toward Residential Energy Conservation in the Pacific Northwest: Overview and Comparisons, Pacific Northwest Laboratory, Richland, Washington, 1984.

An additional report is in progress on the environment for marketing energy conservation to owners of multifamily residential buildings.

The principal topic of this report is the relative importance of energy efficiency to buyers of newly constructed homes in the Pacific Northwest. The investigation has been divided into two documents. This document reviews and evaluates the publicly available literature on the importance of energy efficiency to home buyers. The Bardsley and Haslacher report cited above is a companion report that contains the results of six focus groups convened in June and July 1984 at several Northwest cities to investigate attitudes toward energy efficiency in the home purchase process. Five of the focus groups included people who had either recently purchased a newly constructed home or who were actively seeking a home. One of the groups was composed of real estate brokers and agents.

BPA's programmatic interest in the area of energy conservation was enhanced by Congressional passage of the Pacific Northwest Electric Power Planning and Conservation Act (the "Act") in 1980. (1) The Act established the Northwest Power Planning Council(2) (the "Council") and required the Council to 
prepare and issue a regional conservation and electric power plan (the "plan"). (3) The Plan was subsequently issued in Apri1 1983. (4) Under the Act, BPA is to acquire electric power resources through conservation and otherwise, consistent with the Plan.(5) The Act places the nighest priority on the acquisition of conservation resources. (6) Additionally, BPA is to make the maximusn practicable use of its customers and local entities in implementing conservation programs that require direct arrangements with retail consumers. (7)

The Act required the Council to prepare model conservation standards for new buildings. (8) These standards appear in Appendix $\mathrm{J}$ of the Plan. The Council also prepared energy efficiency standards for conversion of an existing building to electric space conditioning; these appear as Appendix $L$ in the Plan. The Plan requests Northwest regional state governments (Idaho, Montana, Oregon, and Washington), local governments, or utilities to adopt and enforce the model standards by January $1,1986 .{ }^{(9)}$ Utilities that serve areas that are not implementing the model standards are potentially subject to a surcharge on power purchased from BPA. (10)

Several BPA programs relate to the implementation of the model conservation standards. (11) Action item 2.10 in Chapter 10 of the Plan requests BPA to conduct a demonstration program in which builders constructing homes to the model standards prior to January 1, 1986, will receive a subsidy equal to the incremental cost incurred above present energy code requirements. This program, the Residential Standards Demonstration Program, is in place and functioning in the four Northwest states. Action items 2.3, 3.3, 6.4, and 7.3 direct BPA to develop a consistent procedure for sertifying compliance with the model standards. (12) Action item 12.1 directs $B P A$ to develop and implement a program to reimburse state and local governments for the incremental cost of adopting and enforcing the model standards. Later this year BPA also plans to market the "Super Good Cents" program with utilities that choose to participate. Under this program a home built to the model standards, or equivalent code, will be certified and marketed as a "Super Good Cents" home. Participating utilities will inspect the building plans and the installation of energy efficiency features prior to their award of the Super Good Cents certification. 
BPA also plans to offer the Model Standards Consumer Incentive Program through selected utilities. Under this program, builders or those who buy newly constructed homes may receive an incentive averaging about $\$ 1000$ for meeting the model standards.

This report was prepared to support and provide background information for BPA activities related to implementation of the model conservation standards and the Super Good Cents program. Section 3.0 discusses the new home purchase process including the role of energy efficiency in the process. Section 4.0 reviews survey data on the relative importance of reasons to seek a different home and the importance of particular attributes in the home selection process. The role of energy efficiency is emphasized in this discussion. Section 5.0 addresses the relative importance of particular home energy efficiency features and willingness to pay for them. Section 1.0 is an overview of the report. Appendix A contains synopses of the studies reviewed for this report; findings related to the importance of energy efficiency in the home purchase process are summarized. 
1. Public Law 96-501, enacted December 5, 1980.

2. 16 U.S.C.A. 839b(a)(2). Section 4.(a)(2) of the Act.

3. 16 U.S.C.A. 839b(d). Section 4.(d) of the Act.

4. Northwest Power Planning Council, Portland, Oregon, Northwest Conservation and Electric Power Plan, Vol. 1 and 2, April 27, 1983.

5. 16 U.S.C.A. 839(d)(b)(1). Section 6.(b)(1) of the Act.

6. 16 U.S.C.A. 839(b)(e). Section 4.(3) of the Act.

7. 16 U.S.C.A. 839d(e)(2). Section 6.(e)(2) of the Act.

8. 16 U.S.C.A. 839b(f). Section 4.(f) of the Act.

9. Action item 2.1 in Chapter 10 of the $\mathrm{Plan}$ requests implementation for residential buildings; action item 6.1 requests implementation for commercial buildings.

10. 16 U.S.C.A. $839 b(f)(2)$. Section $4 .(f)(2)$ of the Act.

The surcharge issue is briefly discussed in Section 2.2 of P. L. Hendrickson, Pacific Northwest Laboratory, Development of a Procedure to Certify Compl iance with the Northwest Power Planning Council's Model Standards for Energy Conservation in Buildings, prepared for the Office of Conservation, Bonneville Power Administration, August 1984.

11. The programs are further described in BPA Office of Conservation, 1984 Conservation Sourcebook, DOE/BP-261, June 1984.

12. See: P. L. Hendrickson, Ref. 10. 


\subsection{ENERGY EFFICIENCY AND THE NEW HOME PURCHASE PROCESS}

The purchase of a new home is an important transaction for most homebuyers. Frequently, the selection of a home constitutes one of the most important purchase decisions that an individual makes in his lifetime. This chapter briefly addresses some of the many elements that play a part in the home purchase decision process. The impact of energy efficiency considerations on each element is discussed. Elements discussed in the following sections include 1) the fact that many selection attributes affect the decision process, 2) risk factors in the purchase process, 3) the impact of energy efficiency on financing, 4) the decision whether to buy a newly constructed home or an existing home, 5) use of real estate brokers and agents, 6) husband-wife interactions when a home is purchased by a married couple, and 7) sources of energy efficiency information.

\subsection{SELECTION ATTRIBUTES AND THE DECISION PROCESS}

Purchasing a home is a complex process involving many uncertainties and risks. The number of measurable attributes affecting the decision process may be as many as 50 or more. These include obvious concerns such as location, size, and price, and not so obvious concerns such as whether or not the home has a wet bar and access to public transportation. Attributes have different relative importance for each individual. When there are two decision makers in purchasing a home, there must be tradeoffs and compromises that reflect these differences (see Section 3.6 for husband-wife interactions). The relative importance of various selection attributes is discussed in Section 4.2 .

Park ( $\rho$. A.32) concludes that the home purchase process is a "muddling through process" characterized by limited knowledge and, in the case of couples, limited awareness of each spouse's decision strategies. He further concludes, though, that by relying on conflict avoiding techniques and following paths of least resistance, an effective decision can still be made.

The actual techniques and heuristics that are used in the home purchase decision process are difficult to model. Chan, Park, and Yu asked prospective home purchasers about their decision attributes and the relative importance of 
each and used this information to construct an inoividual decision network. (1) Subjects were asked to score each home considered for each decision attribute. The authors then compared the home actually purchased to the subject's weighted attributes. The predictability of the actual home purchased based on the decision attribute network was only fajr. The actual house purchased, however, was nearly always the preferred or second most preferred of at least one of the individual purchasers.

\subsection{RISK FACTORS IN THE PURCHASE PROCESS}

There are many elements of risk in the home purchase process. This section focuses on particular risks associated with the purchase of an energy efficient home and on financial risks.

\subsubsection{Special Risks Associated with Energy Efficient Homes}

There are many uncertainties and risks involved in the new home purchase process. The purchase of an energy efficient house may be viewed as especially risky in several respects. One element of perceived risk may be indoor air quality concerns attributable to low air infiltration. (2) Two other elements relate to the relative newness of highly energy efficient homes. First, the buyer may not be confident that the energy saving features will produce sufficient fuel savings to justify the incremental increase in the initial cost of the home. Second, the buyer may be concerned that the builder did not have sufficient experience to properly install the energy saving features. Both of these concerns related to the newness of the technology, were expressed by homeowners in California who were asked about their perceptions and attitudes toward solar energy. (3)

Housing consumers have a variety of ways to reduce the perceived risks associated with the purchase of energy efficient homes. One study ( $p$. A.3) found that techniques preferred by buyers, in decreasing order of importance, were: asking for equipment warranties, visual inspection, requesting literature, obtaining an independent evaluation, and asking others who purchased 
homes from the builder. In order to counter perceived risks, it may be necessary to increase the amount of consumer information available on energy efficient homes.

In spite of the special risks associated with energy efficient homes, investment theory suggests that buyers should still be willing to pay more for an efficient home, other factors being equal. Empirical research has confirmed that buyers do, in fact, pay more for energy efficient homes. (4)

\subsubsection{Financial Risks}

Two of the elements of the home purchase process that make the process especialiy important and even risky are price negotiation and the terms associated with financing the unpaid balance of the purchase price. The purchaser will naturally be concerned that he obtain the home for the best possible price. The obvious reason is to minimize his initial cost and his periodic payment on any unpaid balance. In addition, the buyer does not want to overpay for a house and face the possibility of taking a loss when the house is subsequently sold in the future.

The financing terms of the sale are also important to the buyer. The buyer must be capable of meeting the periodic loan payment and, in addition, making all his other payments including payments for energy consumption. Until recently, it was difficult for a buyer to overextend on his financing commitments. Banks have very definite guidelines on how much money borrowers can qualify for. The typical guideline is the one included in the Underwriting Guidelines of the Federal Home Loan Mortgage Corporation (FHLMC). This guideline states that the total of interest, principal, insurance, and property taxes should not exceed $28 \%$ of the berrower's stable monthly income and that the borrower's total monthly debt payments should not exceed $36 \%$ of monthly income. However, with the introduction of such features as adjustable interest rate mortgage financing and balloon payments, which are especially comon in conjunction with seller financing, the financing risks facing the home buyer are much greater than previously. 
The percentage of new loans with adjustable interest rates has been rapidly increasing. The national figures compiled by the Federal Home Loan Bank Board shown in Table 3.1 indicate the extent of the increase. (5) Many adjustable rate loans have a maximum interest rate, but this rate is typically 5-7\% higher than the initial rate. When the interest rate is raised, the initial qualifying guidelines can be exceeded.

\section{TABLE 3.1. Percent of New Loans with an} Ad justable Interest: Rate

\begin{tabular}{lcc} 
& $\begin{array}{c}\text { September } \\
1983\end{array}$ & $\begin{array}{c}\text { September } \\
1984\end{array}$ \\
\cline { 2 - 3 } Newly constructed homes & $42 \%$ & $63 \%$ \\
Previously occupied homes & $46 \%$ & $67 \%$
\end{tabular}

A balloon payment provision in a promissory note or real estate contract typically requires the buyer to pay the entire principal balance outstanding at a specific date, usually within five years of purchase of the home. The buyer is then faced with refinancing the outstanding balance at prevailing interest rates, which may be considerably higher than the existing rate.

\subsection{IMPACT OF ENERGY EFFICIENCY ON HOME FINANCING}

The individual who is near the margin of qualifying for a home loan based on the loan/income guidelines referred to in Section 3.2 .2 can potentially receive preferential treatment when purchasing an energy efficient home. Such preferentiai treatment will not be needed by purchasers who can qualify for the home purchase under the normal guidelines or when the home seller is financing the sale. Both the FHLMC ${ }^{(6)}$ and the Federal National Mortgage Association (FNMA) ${ }^{(7)}$ permit their normal loan/income guidelines to be exceeded for energy efficient properties. For example, if the purchaser has an energy rating, a certification, or can otherwise substantiate that he is buying an energy efficient home, the real estate appraiser can attach an energy addendum (FHLMC Form 70A) to his appraisal report. The lender can then exceed the normal FHLMC income guidelines at its discretion and still be reasonably confident that the loan can be sold to FHLMC as long as the loan remains "investment quality." 
FNMA will allow buyers of energy efficient homes to apply up to $30 \%$ of their income to their house payment instead of the normal $28 \%$ limit. In addition, the Department of Housing and Urban Development and the Veterans Administration will insure a higher loan for energy efficient properties. (8)

Nationally, only a limited number of lending institutions currently give preferential loan underwriting treatment to buyers of energy efficient homes. A 1984 study found that only $10 \%$ of lenders offer preferential treatment. (9) Nearly $60 \%$ of lenders, however, reported plans to give preferential treatment. One lender that will give preferential treatment in the state of washington is Rainier Financial Services. It will increase the normal $36 \%$ total debt limit (Section 3.2.2) to $42 \%$ for homes that have a "very efficient" energy rating. (10) Eighteen other lenders in Washington and Oregon either currently give preferential loan treatment for energy efficient homes or $p l a n$ to begin such treatment soon. (11)

Interviewers conducting a study in the Puget Sound area (p. A.8) asked 196 recent home buyers what influence a higher loan/income ratio for an energy efficient house would have on their home selection process. Twenty percent of the respondents said this possibility would be very influential in their selection process, $37 \%$ indicated it would be somewhat influential, $23 \%$ not very influential, $15 \%$ not at a 11 influential, and $5 \%$ did not answer.

\subsection{NEWLY CONSTRUCTED VERSUS EXISTING HOMES}

Home buyers must also decide whether to purchase a newly constructed home or an existing home. The main interest of this investigation is newly constructed homes because these are the homes that will be principally affected by the Council's model conservation standards. Data on the importance to buyers of energy efficiency are rareily segregated by buyers of newly constructed homes versus buyers of existing homes, though. In part, this lack of segregation is because many and probably most home buyers are willing to select the optimal house for them from among all options, and are not firmly committed to a newly constructed or an existing home. Generally, studies reviewed for this investigation covered the topic of the importance of energy efficiency to all home buyers. 
The issue of a newly constructed home versus an existing home cuts across most all home selection decision attributes. For most buyers it is not an attribute itself. To illustrate how it affects other attributes, consider a buyer who wants a detached single-family home, but also wants to be close to the central business district. Such a buyer may find that purchase of a newly constructed home is not possible given his decision attributes. On the other hand, a buyer with a strong preference for contemforary design characteristics and product features may find that purchase of an existing home is not possible.

The impact of a newly constructed home versus an existing home on the energy efficiency decision attribute is relevant to this study. (12) Newly constructed homes presumably meet the existing building energy code for the jurisdiction. Additional energy features beyond code requirements can also be added, although this is generally only done for custom built homes. The prospective buyer of a newly constructed home who has confidence that the energy code is cost-effective, that additional features beyond code requirements are not cost-effective, and that the home is constructed to code, need not be too concerned about the energy efficiency attribute. The statements of the focus group participants confirm this observation. (13) Buyers of existing homes, however, need to be concerned about energy efficiency, although energy efficiency may still be weighted lower than other decision attributes, such as location. An existing home will generally have lcwer energy efficiency than a new home. Energy efficiency features can be retrofitted to the existing home; however, this process generally will be more expersive and less effective than incorporating the features directly into a newly constructed home.

\subsection{USE OF REAL ESTATE AGENTS}

Another decision that the prospective home buyer must make is whether to use a real estate agent in his home search. A knowledgeable agent can potentially be a great help in screening available homes.

Real estate agents will often have access to a multiple listing service (MLS) that will facilitate home screening. This service has traditionally produced a paper catalog of homes listed for sale with real estate firms that are 
local MLS members. More recently, data on MLS homes have been computerized in some geographic areas to facilitate home screening. A very recent innovation is a computer system that enables the buyer to view prospective homes in black and white or color from a variety of angles on a video screen in an agent's office.(14) This type of system should facilitate even further the buyer's process of screening prospective homes.

Sellers rather than buyers typically engage the real estate broker. The broker thus becomes the agent of the seller for the sale transaction. The commission to the broker is payable when the broker or a real estate agent employed by him finds a buyer willing to purchase the property at the price and terms in the listing agreement. Most sellers presumably reflect the commission, at least in part, in their asking price. If a home for sale is listed with a real estate broker other than the broker/agent working with the buyer, the commission will generally be divided between the two brokers and appropriate real estate agents. Buyers who deal directly with a homeowner can perhaps obtain a reduced price because the equivalent of a full real estate commission will ordinarily not be included in the sale price.

A 1981 survey by the National Association of Realtors (p. A.16) found that $85 \%$ of all home sales were handled by licensed real estate agents. The percentage ranged from a high of $96 \%$ agent sales in Baltimore to a low of $73 \%$ agent sales in Miami. In Seattle, $84 \%$ of home sales were handled by a real estate agent.

A real estate agent may be helpful in obtaining past utility cost data for the prospective buyer and in providing some information on a home's energy efficiency. Publications and courses to give agents training on residential energy efficiency have appeared in recent years. (15)

\subsection{HUSBAND-WIFE INTERACTIONS}

At least two researchers (P. A.32 and A.34) have studied the relative importance of particular home purchase decision attributes to husbands and wives. Some generalizations from the studies can be made. In particular, it appears that husbands believe they will have and then actually do have the greatest influence on the home selection attribute of energy efficiency. One 
author ( $p$. A.34) therefore concludes that marketing efforts for a home's energy saving features should be concentrated on husbands. Other attributes, such as home style and interior features and design, tend to be more dominated by the wife.

A recent survey report by RMH Research, Inc., for BPA (p. 2.1) found consistent results. In this survey, the family member most responsible for energy conservation improvements to an existing home was the male ( $43 \%$ of the time) followed by both male and female $(40 \%)$ and the fernale family member $(15 \%) .(16)$ Perhaps what occurs is that each spouse tries to exert their respective influence over attributes that they are most interested in and about which they believe they have the most knowledge. For energy efficiency considerations, it appears that husbands exert the greater influence.

\subsection{SOURCES OF ENERGY EFFICIENCY INFORMATION}

The prospective buyer of a newly constructed or an existing home can benefit from information on a home's energy efficiency. General information on what energy features to look for is available in public libraries and from electric and natural gas utilities, the energy extension service, state energy offices, vendors of energy-conserving products, and, in some cases, real estate agents.

Buyers also need specific energy efficiency information on the particular house in which they are interested. This information can be used to determine how much money to offer for a house, to assess likely monthly energy costs and their affordability, and perhaps to obtain additional funds that would not otherwise be granted by a lending institution (see Section 3.3).

Obtaining reliable information on the energy efficiency of a particular house is not straightforward. One possibility is to simply ask the seller or real estate agent for copies of prior utility bills, preferably for the previous two years. This information can be helpful because it provides "hard" data on what energy costs are likely to be. There are problems with using this data, however. The principal difficulty involves the impact of lifestyle on energy consumption. The existing owner may have a different space conditioning comfort level than the buyer and, thus, may have correspondingly different 
space conditioning costs. In addition, family size and living habits may differ. For example, whether or not the existing family has someone home all day and heats or cools a zone as opposed to the entire home will affect energy costs. Obtaining the past energy consumption data may also be a problem in some cases. The seller may not have the desired data or may not wish to disclose it. In either case, the data can usually, but not aiways, be obtained from the local utility. The buyer will also want to consider whether the weather during the period covered by the utility bills was significantly different than normal.

Another obvious source of information is the buyer's own observations on the energy efficiency of the home of interest. Questions can be asked to obtain as much information as possible. The potential buyer can also utilize knowledgeable acquaintances to help assess a home's energy efficiency or retain a consultant or appraiser to make such an assessment. Builders sometimes include a display of energy efficiency features for newly constructed homes. Surveys have shown (p. A.2) that most buyers desire to have this information in model homes.

A third source of information is the results of an energy audit. Thousands of home energy audits have been conducted in the Northwest in recent years. Most have been conducted by employees of utilities. The National Energy Conservation Policy Act $(17)$ requires utilities with annual natural gas sales of 10 billion cubic feet or more, or 750 million kilowatt-hours of electricity or more to offer home energy audits to their customers on request. (18) The audits are to provide an estimate of installation cost and energy savings available from alternative energy conservation measures. (19) The utility is not required to provide the homeowner with an estimate of the total energy load or consumption for the home. The requirements are administered under the Residential Conservation Service (RCS) program within the U.S. Department of Energy. In addition to the RCS energy audits, many audits have been conducted in the Northwest as part of the BPA Residential Weatherization program. In 1982 and 1983, 209,000 audits were performed under this program. (20) Prospective home purchasers should routinely ask whether an energy audit has been conducted and request a copy of available results. Some 
utilities and local energy conservation offices may disclose the results of any prior audit to prospective home purchasers. The purchaser should also ask which energy conservation measures, if any, were installed subsequently to the audit.

A fourth source of energy efficiency information is the results of a home energy rating or certification program. A home energy rating program funded by BPA has been operating in the Puget Sound area since 1983.(21) The program is being expanded to other cities in the Northwest. The rating provides information on the relative energy efficiency of a particular home. Although the percentage of the housing stock that has been rated is low, purchasers should still inquire whether a rating has been performed. Certain electric utilities in the Northwest will also soon be adopting the "Good Cents" or "Super Good Cents" program (see Sections 1.0 and 2.0) for newly constructed homes. Portland General Electric and PacifiCorp (formerly Pacific Power and Light Co.) will use the Good Cents designation for new homes built to their own predetermined energy standard. BPA will soon be encouraging its customers to adopt the Super Good Cents program. Homes designated "Super Good Cents" must meet the Council's model conservation standard.

One survey ( $p$. A.6) found that home buyers in the Puget Sound area do not aggressively seek energy efficiency information on prospective homes. 0f 196 individuals who had recently purchased a home, $38 \%$ had asked to see fuel bills for the previous year, $11 \%$ asked if there had been a home energy audit, and $3 \%$ requested the seller to have an audit performed. The authors of the same study (p. A.10) queried 25 real estate agents about how often home buyers ask to see fuel bills. Their response was that $20 \%$ always ask, $48 \%$ sometimes ask, and $32 \%$ seldom, if ever, ask to see prior fuel bills. These survey results suggest that energy efficiency, at least in the Puget Sound area, either is not an overriding concern or that home buyers need more information on the availability of energy efficiency information and how to get it. 
1. S. J. Chan, C. W. Park and P. L. Yu, "High-Stake Decision Making--An Empirical Study Based on House Purchase Processes," Human Systems Management, Vol. 3, p. 91, North-Holland Publishing Co., $19 \overline{82 .}$

2. In a recent telephone survey of 603 Oregon residents, $15 \%$ of the respondents indicated they would not take further energy conservation actions on their home because of air quality concerns. H. M. Berg, P. K. Bodenroeder, Survey Research Center, Oregon State University, Attitudes, Opinions and Concerns About Energy - A Survey of Oregon Residents, prepared for the Oregon Department of Energy, Table 8.1, May 1984.

3. J. 8. Margolin and M. R. Misch, Behavioral Studies Group, George Washington IJniversity, California Solar Energy Study: Decision-Analys is Panel Report, prepared for the California Energy Commission, September 1979.

4. R. C. Johnson, Housing Market Capitalization of Energy-Saving Durable Good Investments, ORNL/CON-74, Oak Ridge National Laboratory, July 1981. See also Longstreth, P. A.36.

5. "Federal Home Loan Bank Board News," October 4, 1984, Washington, D.C.

6. FHLMC Sellers' Guide, Section 3.201A.

7. Federal National Mortgage Association Lending Guide, Sections 102.05, and 103.03.

8. S. J. Foute, et al., "Energy Mortgage Valuation: From Theory to Practice," The Real Estate Appraiser and Analyst, Journal of the Society of Real Estate Appraisers, Chicago, I7linois, p. 23, Summer 1984.

9. The survey was conducted by the firm of Burson Marsteller Research, New York City, and was sponsored by the Owens-Corning Fiberglas Corp., Toledo, Ohio. The results are reported in Solar Energy Intelligence Report, Silver Spring, Maryland, April 23, 1984, p. 137.

10. A. M. Patton and J. F. Parker, Residential Energy Evaluation Program: Evaluation and Summary, WAOENG-84-09, Washington State Energy Office, OTympia, Washington, P. E-1, March 1984.

11. Northwest Power Planning Counci1, Northwest Energy News, Vo1. 3, No. 5, p. 21, September/October 1984.

12. A more detailed discussion of the economic choice between new and old units is in D. M. Jaffee, "New Residential Construction and Energy Costs," which appears in $A$. Downs and $K$. L. Bradbury, editors, Energy Costs, Urban Development, and Housing, $p .163$, the Brookings Institution, Washington, D.C., 1984 . 
13. Bardsley and Haslacher, Inc., Portland, Oregon, Northwest New Home Buyers Discuss the Home Purchase Decision, October 1984.

14. The Wall Street Journal, July 18, 1984, p. 29.

15. National Association of Realtors, Residential Construction and Energy, publication number 151-1118, Chicago, Illinois, 1980. National Association of Realtors, The Realtors Guide to Residential Energy Efficiency: An Introduction in Using Energy to Sell Homes.

16. RMH Research, Inc., River Edge, N.J., Marketing Environment for Energy Conservation in the Pacific Northwest, Table 19, May 1984.

17. 42 U.S.C.A. 8212. Title II of the National Energy Conservation Policy Act, enacted in 1978, established this requirement as part of the Residential Conservation Service Program administered by the Department of Energy. In addition, Section 367 of the Energy Conservation and Production Act, Public Law 94-385 enacted in 1976, requires state energy conservation plans to establish procedures for encouraging and carrying out energy audits in order to receive federal financial assistance. All states are in compliance with this requirement. Annual Report to the President and the Congress on the State Energy Conservation Program for Calendar Year 1981, DOE/CE-0016, P. 6, July 1982.

18. 10 C.F.R. $456.105(c)$.

19. 10 C.F.R. 456.306 .

20. Eric Hirst, Oak Ridge National Laboratory, Evaluation of Utility Home Energy Audit (RCS) Programs, included in VoT. G of the proceedings of the August 1984 Summer Study on Energy Efficiency in Buildings sponsored by the American Council for an Energy-Efficient Economy, Washington, D.C.

21. Ref. 10 contains an evaluation of the progran. 


\subsection{ROLE OF ENERGY EFFICIENCY IN DECISIONS TO SEEX AND SELECT NEW HOUSING}

This chapter is divided into two parts. In Section 4.1 , the results of surveys discussing reasons why individuals seek new housing are reviewed. The relative importance of particular housing selection attributes once a decision to purchase a new home has been made is discussed in Section 4.2. Both sections are largely drawn from the studies highlighted in Appendix $A$, and both include information on the relative importance of energy efficiency.

\subsection{RELATIVE IMPORTANCE OF REASONS TO SEEX NEW HOUSING}

This section discusses the results of surveys on the relative importance of various reasons for buying a different house. Buyers can be in the home market in their existing geographic location or at a new location. The discussion primarily addresses reasons to buy a new home within a given geographic location. The underlying reasons for moving to a new location, e.g., job change, different climate preference, etc., are mentioned briefly.

The most recent data found on reasons for buying a new home are from surveys undertaken by Professional Builder and Builder magazines. The Professional Builder survey (pp. A.1-A.3) is conducted annually. The most recent survey was conducted in August 1983 and covered 475 households that indicated their intention to purchase a home in the immediate future. The most significant reason for buying was to obtain a larger home. This reason was even more pronounced on the Pacific coast. A better geographic location was the second most cited reason. A desire for a more energy efficient home ranked as the fifth most cited reason $(8.4 \%)$ nationaliy for buying a new home, but was rated considerably lower $(2.6 \%)$ by households on the Pacific coast. The Pacific coast region in the survey included California, Oregon, and Washington. Responses were presumably affected by California's mild climate.

The Builder survey ( $\mathrm{pp}$. A.4-A.5) was conducted during the latter half of 1983 and covered 2,176 prospective home buyers who visited model homes in newly constructed home complexes. These individuals were thus more likely to be interested in the purchase of a newly constructed home than the Professional Builder sample, which represented a general sample of individuals who expected 
to purchase a home. The results of the Builder survey were quite different from the Professional Builder survey. In the Builder sample, acquiring a more energy efficient home was the most often cited motivating factor for buying a new home for current homeowners. For respondents that currently rent, a desire to cease renting and tax advantages were cited first and second, respectively. Purchase of a more energy efficient home was the third most cited reason for purchasing a new home.

The results of the two surveys are puzzling in the widely differing importance of energy efficiency as a reason to buy a different home. A possible explanation is that the respondents in the Builder survey were asked to check all applicable items that would encourage them to purchase a new home. Since most potential buyers are at least interested in energy efficiency, it was frequently cited. In any case, comparison of the two survey results suggests that buyers who are interested in newly constructed homes, weigh greater energy efficiency higher as a reason to buy than do home buyers in general.

A 1981 survey (p. A.15) found that 45\% of individuals who visited model home complexes were only considering newly constructed homes; $55 \%$ were also considering the purchase of an existing home. Compared to the Builder survey, the same study found a lower, but still significant percentage (25\%) of respondents who listed improved energy efficiency as a reason to buy a new home.

A 1981 study involving two focus groups (p. A.18) also found that prospective buyers of newly constructed homes are more interested in energy efficiency than buyers of existing homes.

\subsection{RELATIVE IMPORTANCE OF PARTICULAR ATTR IBUTES IN HOME SELECTION}

This section discusses survey results that address the relative importance of particular attributes in the home selection process once a decision to buy has been made. The topic is closely related to the issue of reasons for purchasing a new home discussed in Section 4.1, and the literature is sometimes confusing on which topic is being surveyed.

The two attributes that appear to be the most important in selecting a new home are price and location. Common sense suggests this result, and survey 
results confirm it. A 1983 survey of home buyers in the Puget Sound area (p. A.6) for example, found that most buyers listed location first and price second as the most important considerations in selecting a new home. A 1980 survey by the National Association of Home Builders (NAHB) found that among those who purchased newly constructed homes in 1977 or 1978 neighborhood was cited most frequently as the most important attribute in home selection (p. A.12). A 1980 survey in eastern Oregon and Washington (p. A.29) found price and neighborhood to be the two most important attributes in the home selection process.

After price and location, the attributes of size, design, and construction quality appear to be most important. In the Puget Sound study (p. A.6) design was ranked as the third most important attribute and size as fourth. In the NAHB study (p. A.12) quality of workmanship was listed after neighborhood as the most - mportant feature among those who had purchased a newly constructed home. A related attribute, the builder's reputation, was ranked third. In the eastern 0regon and Washington study, floor plan was ranked fourth, quality of construction fifth, and house size eighth among selection attributes. Another study ( $p$. A.30) led to the ranking of 17 selection attributes by 150 individuais who had purchased a home. Safety from crime, an attribute related to location, was listed as the most important attribute followed by construction quality. The amount of living space was the fourth most important attribute. This was the only study reviewed where safety from crime was used as a specific selection attribute.

After the five preceding attributes, energy efficiency appears to be at least as important as any other attribute. In the eastern Oregon and Washington study (p. A.29) the level of insulation was the third most important selection attribute. In the Puget Sound study (p. A.6) energy efficiency was the sixth most important consideration in home selection. Finally, in the NAHB study (p. A.12) energy saving features were the fifth most important consideration nationally and were seventh in the Pacific region (Alaska, California, Hawaii, Oregon, and Washington) among the sample who had purchased newly constructed homes in 1977 or 1978. The ranking of selection attributes in the surveys discussed above are summarized in Table 4.1. 
TABLE 4.1. Relative Importance of Selection Attributes to Individuals Who had Purchased a New Home

\begin{tabular}{|c|c|c|c|c|c|}
\hline & NAHB & NAHB & $\begin{array}{c}\text { State of } \\
\text { Washington }\end{array}$ & PNL & Frelder/Blble \\
\hline Page & A. 12 & A. 12 & A. 6 & A. 28 & A. 30 \\
\hline Survey date: & 1980 & 1980 & 1983 & 1980 & 1977 \\
\hline Sample slze: & 1249 & 89 & 196 & 35 & 150 \\
\hline Location: & Natlonal & Paciflc stotes & Puget Sound & $\begin{array}{l}\text { Eastern Oregon, } \\
\text { Washington }\end{array}$ & Midwast \\
\hline Home type: & Newly constructed & Newly constructed & All types & Newly constructed & All types \\
\hline $\begin{array}{l}\text { Selection } \\
\text { Attrlbutes } \\
\text { LIsted in } \\
\text { Order of } \\
\text { Importance }\end{array}$ & $\begin{array}{l}\text { - Nelghborhood } \\
\text { - Qualtity of } \\
\text { workmansh lp } \\
\text { - Warranty } \\
\text { - Reputation of } \\
\text { butider } \\
\text { - Energy-saving } \\
\text { features } \\
\text { - Proximlty to mork } \\
\text { - School distrlct }\end{array}$ & $\begin{array}{l}\text { - Nelghborhood } \\
\text { - Quality of } \\
\text { morkmanshlp } \\
\text { - Warranty } \\
\text { - Reputatlon of } \\
\text { bullder } \\
\text { - Proxlmity to work } \\
\text { - School district } \\
\text { - Energy-savlng } \\
\text { features }\end{array}$ & $\begin{array}{l}\text { - Location } \\
\text { - Price } \\
\text { - Design } \\
\text { - Size } \\
\text { - Nelghborhood } \\
\text { - Energy effl- } \\
\text { clency }\end{array}$ & $\begin{array}{l}\text { - Price } \\
\text { - Nelghborhood } \\
\text { - Insulation } \\
\text { - Floor plan } \\
\text { - Construction } \\
\text { quality } \\
\text { - Garage } \\
\text { - Location }\end{array}$ & $\begin{array}{l}\text { - Safety from } \\
\text { crime } \\
\text { - Constructlon } \\
\text { quality } \\
\text { - School quality } \\
\text { - LIving space } \\
\text { - Storage space } \\
\text { - Property values } \\
\text { - Yard slze }\end{array}$ \\
\hline
\end{tabular}


The NAHB respondents were also asked what the most important considerations would be if they were to move to a different (not necessarily newly constructed) nome. Greater energy efficiency was listed as the most important consideration both nationally and among the Pacific region respondents. Note that this result does not imply that increased energy efficiency is a reason to move, but that if the respondents were to move, greater energy efficiency would be the most important consideration in home selection. When the same respondents in the NAHB study were asked what features would be important if they were to buy another newly constructed home, energy saving features were ranked third in the Pacific region states and, nationally, were virtually tied for second (after quality of workmanship) with neighborhood and builder reputation. Energy efficiency was thus much more highly weighted as a selection attribute for the respondent's next home than for the home they had purchased in 1977 or 1978.

Finally, the results in Section 4.1 on reasons to seek new housing relate indirectly to the relative importance of selection attributes. Thus the respondents and the Builder survey ( $P$. A.4) who rated a more energy efficient home very highly as a reason to purchase a different home could probably be expected to weight energy efficiency high among selection attributes once a decision was made to purchase. 


\subsection{IMPORTANCE OF PARTICULAR ENERGY EFFICIENCY FEATURES}

AND WILLINGNESS TO PAY FOR THEM

This section discusses two topics. Section 5.1 discusses survey results on the relative importance of particular home energy efficiency features. Section 5.2 discusses the willingness of home owners and home buyers to pay for energy efficiency improvements.

\subsection{RELATIVE IMPORTANCE OF PARTICULAR ENERGY EFF ICIENCY FEATURES}

Survey results indicate that the energy efficiency features home buyers are most interested in are insulation (ceiling, wall, and floor, in decreasing order of -mportance) followed by extra window glazing, and appropriate weatherstripping and caulking. In the Puget Sound study (p. A.8) of individuals who had purchased a home in 1983, the 4 most important energy conservation features in decreasing order were ceiling insulation, storm windows, and wall and floor insulation. In a 1979 North Carolina study (p. A.26) respondents were asked what energy saving features they would most likely look for in their next home. Fifty-one percent of prospective home buyers would be most interested in insulation and extra glazing. Nineteen percent would be most interested in energy efficient appliances. In another 1979 study involving 1000 homeowners (p. A.22) insulation, storm windows and doors, and weather stripping were cited as the most desired energy saving features. The 1983 Professional Builder survey ( $p$. A.2) asked respondents about optional energy saving features that would be selected for a newly constructed home. Nationally, an energy saving water heater was named first by most respondents, followed by storm windows, storm doors, zoned heating/cooling, double glazing, and insulated basement walls. Ceiling and wall insulation and weatherstripping were not offered as choices to respondents, presumably under the assumption that they would be adequately included as part of the standard package of a newly constructed home. Finally, in a 1981 survey ( $P$. A.15) upgraded insulation and double-pane windows were the energy efficiency improvements that buyers of newly constructed homes were most likely to spend extra for. 


\subsection{WILLINGNESS TO PAY FOR ENERGY EFF ICIENCY IMPROVEMENTS}

A number of surveys have asked respondents about their willingness to invest in energy efficiency improvements to an existing home or a newly constructed home. The survey data are summarized in Table 5.1.

It is difficult to draw specific conclusions from the data. The Professional Builder data (P. A.1) are interesting, though, and suggest a pattern. In the 1981 Professional Builder survey, $78 \%$ of respondents indicated they would be willing to spend $\$ 1000$ initially to save $\$ 100 / y r$ on fuel bills. The question was apparently worded to apply only to newly constructed homes. The percentage dropped to $71 \%$ in the 1982 survey and $64 \%$ in the 1983 survey. The 1983 number for the Pacific states of California, Oregon, and Washington was 63\%. A $\$ 100$ annual saving for 20 years implies an approximate $8 \%$ nominal discount rate with an initial $\$ 1000$ investment. The decreasing percentage can be interpreted several ways including: 1) consumers are expecting higher future interest rates; 2) consumers are expecting moderating future energy prices; 3) both 1) and 2); or 4) consumers are increasingly interested in other housing attributes besides energy efficiency.

TABLE 5.1. Willingness to Spend on Energy Efficiency Improvements

\begin{tabular}{|c|c|c|c|c|c|}
\hline $\begin{array}{c}\text { Reference } \\
\text { Page } \\
\end{array}$ & $\begin{array}{c}\text { Survey } \\
\text { Date } \\
\end{array}$ & $\begin{array}{l}\text { Sample } \\
\text { Size } \\
\end{array}$ & $\begin{array}{c}\text { Estimated Annual } \\
\text { Saving }(\$) \\
\end{array}$ & $\begin{array}{c}\text { Capital } \\
\text { Investment }(\$)\end{array}$ & $\begin{array}{l}\% \text { Willing } \\
\text { to Invest }\end{array}$ \\
\hline A. 29 & 1980 & 35 & $\$ 100$ & $\$ 600$ & $94 \%$ \\
\hline A. 26 & 1979 & 79 & 50 & 200 & 90 \\
\hline A.26 & 1979 & 79 & 100 & 600 & 85 \\
\hline A. 26 & 1979 & 79 & $\begin{array}{l}33 \% \text { of space con- } \\
\text { ditioning costs }\end{array}$ & 1200 & 80 \\
\hline A. 22 & 1979 & 1000 & $\begin{array}{l}25 \% \text { of space con- } \\
\text { ditioning costs }\end{array}$ & 1362 & $\begin{array}{l}\$ 1362 \text { is } \\
\text { average of } \\
\text { responses }\end{array}$ \\
\hline A.1 & 1981 & 780 & 100 & 1000 & 78 \\
\hline A.1 & 1982 & 527 & 100 & 1000 & 71 \\
\hline A.1 & 1983 & 475 & 100 & 1000 & 64 \\
\hline
\end{tabular}


In a recent telephone survey of 603 Oregon residents, $76 \%$ of respondents indicated they would be willing to pay an additional $\$ 75 / y r$ for four years for a very energy efficient house. (1) No estimate of fuel savings was included in the question. 


\section{REFERENCES AND NOTES FOR SECTION 5.0}

1. H. M. Berg, P. K. Bodenroeder, Survey Research Center, Oregon State University, Attitudes, Opinions and Concerns about Energy - A Survey of Oregon Residents, prepared for the Oregon Department of Energy, Table 3.2, May 1984. 


\section{ABBREVIATIONS}

Act Pacific Northwest Electric Power Planning and Conservation Act

BPA Bonneville Power Administration

CFR Code of Federal Regulations

Council Northwest Power Planning Council

FHLMC Federal Home Loan Mortgage Corporation

NAHB National Association of Home Builders

PNL Pacific Northwest Laboratory

Plan Northwest Conservation and Electric Power Plan

U.S.C.A. United States Code Annotated 
HIGHLIGHTS OF SURVEYS AND DOCUMENTS REVIEWED FOR THE REPORT 
1. Iitle: National Consumer/Builder Survey on Housing

Author: Professional Builder Magazine

Cahners Publishing

Des Plaines, Illinois

Date: Annual survey conducted in August and published in the December issue of the magazine.

Sample: Households that expect to buy a home in the immediate future. Sample size: $1981 \quad 780$

$1982 \quad 527$

1983475 (78 from Pacific Coast - California, Oregon, and Washington)

Objectives: Gather information on preferences of individuals planning to buy a home.

Approach: Consumers completed and mailed a written questionnaire.

Relevant Findings:

1. Willingness to spend $\$ 1000$ initially to save $\$ 100 / y r$ on energy costs:

\begin{tabular}{|c|c|c|c|c|c|}
\hline & \multirow[b]{2}{*}{$\begin{array}{l}1981 \\
(\%) \\
\end{array}$} & \multirow[b]{2}{*}{$\begin{array}{l}1982 \\
(\%) \\
\end{array}$} & \multicolumn{2}{|c|}{$1983(\%)$} \\
\hline & & & & $\begin{array}{c}\text { All } \\
\text { Regions } \\
\end{array}$ & $\begin{array}{l}\overline{\text { Pacific }} \\
\text { Coast }\end{array}$ \\
\hline Yes & & 64.8 & 49.7 & 49.3 & 47.4 \\
\hline & $\begin{array}{l}\text { - more than } \\
\$ 1000\end{array}$ & 13.2 & 21.3 & 14.9 & 15.4 \\
\hline Sub & total & 78.0 & 71.0 & 64.2 & 62.8 \\
\hline No & $\begin{array}{l}\text { - recovery period } \\
\text { too long }\end{array}$ & 17.6 & 21.3 & 22.7 & 24.4 \\
\hline No & $\begin{array}{l}\text { - energy savings } \\
\text { claims not } \\
\text { believable }\end{array}$ & 7.9 & 7.7 & 11.2 & 12.8 \\
\hline
\end{tabular}


2. Optional energy saving features that would definitely be selected as part of a newly constructed home:

\begin{tabular}{|c|c|c|c|c|}
\hline & \multirow[b]{2}{*}{$\begin{array}{l}1981 \\
(y) \\
\end{array}$} & \multirow[b]{2}{*}{$\begin{array}{l}1982 \\
(\%)\end{array}$} & \multicolumn{2}{|c|}{$1983(\%)$} \\
\hline & & & $\begin{array}{c}\bar{A} \overline{1} \\
\text { Regions } \\
\end{array}$ & $\begin{array}{l}\text { Pacific } \\
\text { Coast }\end{array}$ \\
\hline Triple glazing & 13.7 & 15.6 & 15.2 & 7.7 \\
\hline Double glazing & 24.6 & 35.7 & 34.6 & 34.7 \\
\hline Storm windows & 59.8 & 48.2 & 48.6 & 10.3 \\
\hline Storm doors & 55.0 & 46.7 & 47.6 & 10.3 \\
\hline Window sunshades & 7.8 & 8.0 & 6.7 & 6.4 \\
\hline $\begin{array}{l}\text { Insulated basement } \\
\text { walls }\end{array}$ & $3 \overrightarrow{5} .0$ & 29.8 & 28.2 & 10.3 \\
\hline Solar water heating & 21.1 & 25.8 & 18.7 & 32.1 \\
\hline $\begin{array}{l}\text { Energy saving } \\
\text { water heater }\end{array}$ & 45.1 & 62.6 & 54.7 & 51.3 \\
\hline Clock thermostat & 19.1 & 21.6 & 19.8 & 10.3 \\
\hline Zoned heating/cooling & 35.3 & 48.4 & 40.8 & 35.9 \\
\hline Power attic vent & 29.5 & 27.7 & 24.4 & 14.1 \\
\hline
\end{tabular}

3. Percent desiring display of energy saving features in model homes:

$$
\begin{aligned}
& 1981=59.8 \% \\
& 1983=55.6 \% .
\end{aligned}
$$


4. Existing homeowner's primary reason for buying a different home:

\begin{tabular}{lcc} 
& \multicolumn{2}{c}{1983} \\
\cline { 2 - 3 } & $\begin{array}{l}\text { All Regions } \\
(\%)\end{array}$ & $\begin{array}{c}\text { Pacific Coast } \\
(\%)\end{array}$ \\
\cline { 2 - 3 } $\begin{array}{l}23.8 \\
\text { Larger home }\end{array}$ & 32.1 \\
Metter location & 21.5 & 23.1 \\
To realize profit on & 11.6 & 9.0 \\
$\quad$ existing home & 10.3 & 11.5 \\
More energy efficient & & \\
$\quad$ home & 8.4 & 2.6 \\
Less maintenance & 8.0 & 7.7 \\
New home & 6.9 & 2.6 \\
Sinaller home & 6.7 & 3.8 \\
More prestigious & & 2.6 \\
neighborhood & 3.2 & 2.6 \\
More community features & 1.9 &
\end{tabular}

5. Ways used to determine credibility of energyefficiency claims:

Ask for guarantees/warranties

1983

$\%$

Visual inspection

51

Ask for literature

45

Get independent evaluation

38

Ask others who bought from builder

33

Look at product brand names

33

Compare to other homes

27

Rely on builder's word

27

8 
2. Title: What Buyers Want: A 1984 Survey of Prospective New Home Buyers adapted from the Builder Magazine 1984 National Home Shoppers Survey, Reports 1-14.

Authors: Builder Magazine,

The magazine of the National Association of Home Builders Washington, D.C.

George A. Fulton Research and Consulting, Fairfax, Virginia.

Date: $\quad$ April 1984 issue of Builder

Objectives: Analyze the feature preferences in newly constructed homes for three buying categories:

1. Prospective buyers who currently rent their residence

2. Prospective buyers who currently own their residence

3. "Empty-nesters"--home shoppers 45 years or older with no children at home.

Breakdowns of the survey data by household income for categories 1 and 2 can be purchased from the authors.

Sample: Prospective home buyers who visited model homes in complexes of newly constructed homes during the second half of 1983. The six markets surveyed were: Boston; St. Louis; Houston; Portland, Oregon; Washington, O.C. suburbs; and southern California.

Sample Distribution:

$\begin{array}{lr}\text { Renters } & 674 \text { (including } 37 \text { empty-nesters) } \\ \text { Owners } & 1,477 \text { (including } 272 \text { empty-nesters) } \\ \text { Empty-Nesters } & 309\end{array}$

Relevant findings: Items that would most encourage respondents to purchase a new home. Respondents were asked to check all applicable items. 


\begin{tabular}{|c|c|c|c|}
\hline & Renters & Owners & $\begin{array}{l}\text { Empty- } \\
\text { Nesters } \\
\end{array}$ \\
\hline A more energy-efficient home & $52 \%$ & $53 \%$ & $54 \%$ \\
\hline Larger home & 42 & 50 & 17 \\
\hline New design features & 32 & 37 & 38 \\
\hline Tax advantages & $63 \%$ & $35 \%$ & $31 \%$ \\
\hline Better neighborhood & 34 & 30 & 19 \\
\hline Less yard maintenance & 19 & 30 & 51 \\
\hline Investment potential & 43 & 31 & 23 \\
\hline New product features & 22 & 26 & 30 \\
\hline Larger yard & 28 & 25 & 8 \\
\hline Growing family & 22 & 17 & 1 \\
\hline Change of scene & 11 & 15 & 15 \\
\hline Fewer people living at home & 4 & 18 & 44 \\
\hline Better schools & 18 & 16 & 1 \\
\hline Closer to work & 17 & 14 & 9 \\
\hline $\begin{array}{l}\text { Community recreation } \\
\text { facilities }\end{array}$ & 12 & 12 & 9 \\
\hline Tired of renting & 58 & 2 & 10 \\
\hline Smaller home & 6 & 14 & 38 \\
\hline Community security system & 10 & 8 & 14 \\
\hline Job transfer & 7 & 8 & 6 \\
\hline Recent or future marriage & 17 & 5 & 2 \\
\hline Recent divorce/separation & 4 & 2 & 2 \\
\hline To use as rental property & 2 & 3 & 3 \\
\hline
\end{tabular}


3. Title: Surveys in Support of the Residential Energy Evaluation Program

Authors: Kurt Wehbring, David Dornbusch \& Co., Portland, Oregon

Adam Davis, Northwest Attitudes, Portland, Oregon

Publications: The surveys are included as Appendix $G$ in A. M. Patton and J. F. Parker, Washington State Energy Office, 01 ympia, Washington, Residential Energy Evaluation Program: Summary and Evaluation, WAOENG 84-09, March 1984.

Date: The surveys were conducted in the summer of 1983.

Objective: The principal objective of the surveys was to determine the impact on the shelter industry of a pilot program on home energy ratings, and to obtain information to improve and strengthen the program.

Sample: The surveys involved telephone interviews with real estate appraisers, loan offices, real estate agents, home sellers, and home buyers in the Puget Sound area. 25 real estate agents and 196 home buyers who had purchased a home within the last year were interviewed.

Relevant Findings: HOME BUYERS

1. What were the most important considerations in selecting your home?

Consideration

Location (near family, friends, job, shopping

Price

Building design, aesthetics

Amount of space

Quality of neighborhood

Energy efficiency

Financing

Schools

Landscaping, yard
Percent of Times

Mentioned by

Rank Respondents

$60 \%$

54

48

33

31

22

11

11

10 
2. When you were looking for a house to buy, was the energy efficiency of the house very important, somewhat important, not very important or not at all important?

$\begin{array}{lc}\text { Very important } & 31 \% \\ \text { Somewhat important } & 49 \\ \text { Not very important } & 13 \\ \text { Not at all important } & \frac{7}{100 \%} \\ \text { Total } & \end{array}$

3. Did you ask the seller to provide you with the fuel bills for the last year?

Yes $38 \%$

No 60

$\begin{array}{ll}\text { Don't know } & \frac{2}{100 \%} \\ \text { Total } & 10 \%\end{array}$

4. Did you ask the seller if there had been a home energy audit? Yes $\quad 11 \%$

No 86

Don't know

Total 100\%

5. Did you ask the seller to have a home energy audit conducted?

Yes $3 \%$

No 86

Don't know

Total 100\% 
6. What energy conservation features of the house you bought did you feel were important?

\begin{tabular}{lccc}
\multicolumn{1}{c}{ Feature } & Rank & $\begin{array}{c}\text { Percent cf Times } \\
\text { Improvertent Was } \\
\text { Mentioned }\end{array}$ \\
\cline { 1 - 2 } Ceiling insulation & 1 & $38 \%$ \\
Storm windows & 2 & 36 \\
Wall insulation & 3 & 31 \\
Floor insulation & 4 & 21 \\
Hot-water heater wrap & 5 & 17 \\
Type of furnace & 6 & 13 \\
Weatherstripping/caulking & 7 & 12 \\
Woodstove & 8 & 5 \\
Clock thermostat & 9 & 6 \\
Solar space heating & 10 & 4 \\
Insulated ducts, pipe & 10 & 4 \\
Solar water heating & 11 & 2
\end{tabular}

7. If you could get a larger mortgage for an enargy-efficient house, how influential would the larger mortgage be in selecting a house to buy? Very influential 20\%

Somewhat influential 37

Not very influential 23

Not at all influential 15

Don't know, refused $\quad 5$

Total 100\% 


\section{REAL ESTATE AGENTS}

1. When establishing the offering sale price of a house, do you think that the energy efficiency of the house is very important, somewhat important, not very important, or not at all important?

$\begin{array}{lc}\text { Very important } & 44 \% \\ \text { Somewhat important } & 48 \\ \text { Not important } & \frac{8}{100 \%} \\ \text { Total } & \end{array}$

2. When selling a house, do you think a house that is energy efficient is definitely easier to sell, somewhat easier to sell, or doesn't make much difference?

$\begin{array}{lc}\text { Easier } & 48 \% \\ \text { Somewhat easier } & 32 \\ \text { No difference } & \frac{20}{100 \%} \\ \text { Total } & \end{array}$

3. Do you ever encourage or recommend a seller to make energy efficiency improvements to a house prior to selling the home, such as adding storm windows or insulation?

$\begin{array}{ll}\text { Yes } & 44 \% \\ \text { No } & \frac{56}{100 \%} \\ \text { Total } & 10 \%\end{array}$

4. (For those who answered yes in question 3.) Why do you recommend energy efficiency improvements?

$(N=11)$

\begin{tabular}{|c|c|c|c|}
\hline & Mention & $\begin{array}{c}\text { Not } \\
\text { Mention }\end{array}$ & $\begin{array}{l}\text { Don't Know } \\
\text { or Refused } \\
\end{array}$ \\
\hline Increases resale value & $55 \%$ & $18 \%$ & $27 \%$ \\
\hline Improves appearance & 9 & 55 & 36 \\
\hline Increases loan amount & 9 & 55 & 36 \\
\hline
\end{tabular}


5. Which do you think are the three most important energy efficiency selling features?

\section{Frequency Mentioned}

Storm windows $36 \%$

Attic insulation

Heat pump

12

6. When a homebuyer evaluates a house, to what extent do you think energy use and efficiency is a factor in the purchase decision?

$\begin{array}{lc}\text { Very important } & 40 \% \\ \text { Somewhat important } & 44 \\ \text { Not very important } & 12 \\ \text { Not at all important } & 4 \\ \text { Total } & 100 \%\end{array}$

7. In your experience, how often do potential homebuyers ask to see the annual fuel bills: always, sometimes, seldom if ever?

$\begin{array}{lc}\text { Always } & 20 \% \\ \text { Sometimes } & 48 \\ \text { Seldom, if ever } & \frac{32}{100 \%} \\ \text { Total } & \end{array}$

8. In estimating their monthly carrying charges, how of ten do homebuyers presently include the fuel costs in their calculations: always, sometimes, seldom if ever?

$\begin{array}{lc}\text { Always } & 20 \% \\ \text { Sometimes } & 48 \\ \text { Seldom, if ever } & \frac{32}{100 \%} \\ \text { Total } & \end{array}$


4. Title: Decisions for the 1980s

Author: Economics Division, National Association of Home Builders, Washington, D.C.

Sample: Approximately 1250 individuals including 89 in the Pacific region who purchased a newly constructed home in 1977 or 1978 . The survey was administered in the fall of 1980 .

Objective: Survey the attitudes, preferences, interests, and outlook of new home buyers.

Relevant Findings: A number of energy related questions were asked during the survey. The survey results were broken out by census region. Tables $A .1$ and A.2 present the results for the Pacific region (California, Oregon, Washington, Alaska, and Hawaii) and the total results for the entire United States. The tables are also reproduced with complete regional information at pages 150-153 of A. Downs, editor, Energy Costs, Urban Development, and Housing, The Brookings Institution, Washington, D.C., 1984. 
TABLE A.1. What Consumers Seek in the Purchase of a Home (percent of respondents)

Question and Response Pacific Total

If you were going to move, what would be the most important considerations in your selection of a home?

$\begin{array}{lcc}\text { Greater energy efficiency } & 68.2 \% & 79.5 \% \\ \text { Larger lot } & 50.0 & 39.8 \\ \text { Larger house } & 42.0 & 42.7 \\ \text { Better neighborhood } & 31.8 & 25.1 \\ \text { New house } & 30.7 & 34.9 \\ & & \\ \text { Smaller house } & 14.8 & 9.9 \\ \text { Smaller lot } & 2.3 & 4.6 \\ \text { Old home to rehabilitate } & 5.7 & 5.2 \\ \text { Older home } & 1.7 & 3.1 \\ \text { More luxury features } & 30.7 & 31.2 \\ & & \\ \text { Low-tax neighborhood } & 9.1 & 20.4 \\ \text { Condominium or cooperative } & 1.1 & 3.7 \\ \text { Town house } & 2.3 & 3.4 \\ \text { Mobile home } & 1.1 & 0.5 \\ \text { Inter-city location } & 4.5 & 2.1 \\ \text { Other } & 11.4 & 8.2 \\ & & \\ \text { Number of respondents } & 88 & 1,218\end{array}$

What features were important to you when you bought a new home?

$\begin{array}{lcc}\text { Reputation of builder } & 58.4 \% & 66.3 \% \\ \text { Neighborhood } & 89.9 & 89.1 \\ \text { Quality of workmanship } & 77.5 & 78.0 \\ \text { Warranty } & 73.0 & 71.0 \\ \text { Proximity to shopping area } & 43.8 & 38.1 \\ & & \\ \text { Proximity to work } & 57.3 & 50.8 \\ \text { School district } & 52.8 & 47.1 \\ \text { Energy-saving features } & 51.7 & 60.3 \\ \text { Recommendation of another buyer } & 7.9 & 7.7 \\ \text { Other } & 11.2 & 11.8 \\ & & \\ \text { Number of respondents } & 89 & 1,249\end{array}$


TABLE A.1. (contd)

Question and Response Pacific Total

What features would be important to you if you were buying another new home?

$\begin{array}{lll}\text { Reputation of builder } & 67.9 \% & 79.9 \% \\ \text { Neighborhood } & 78.2 & 80.1 \\ \text { Quality of workmanship } & 84.6 & 85.4 \\ \text { Warranty } & 62.8 & 66.5 \\ \text { Proximity to shopping area } & 50.0 & 44.9 \\ & & \\ \text { Proximity to work } & 65.4 & 58.9 \\ \text { School district } & 47.4 & 51.7 \\ \text { Energy-saving features } & 75.6 & 78.7 \\ \text { Recommendation of another buyer } & 10.3 & 14.5 \\ \text { Other } & 10.3 & 11.7 \\ & & \\ \text { Number of respondents } & 78 & 1,107\end{array}$

Was your new home advertised as energy-efficient?

$\begin{array}{lcc}\text { Yes } & 28.7 \% & 45.8 \% \\ \text { No } & 66.7 & 42.8 \\ \text { Oo not remember } & 4.6 & 11.3 \\ \text { Total } & 100.0 & 100.0 \\ \text { Number of respondents } & 87 & 1,226\end{array}$

What type of house would you prefer to buy?

Single-family detached

Single-family, attached

Duplex

Low-rise condominium

Mid-rise condominium

High-rise condominium

Mobile home

Total

Number of respondents

$\begin{array}{cc}95.5 \% & 92.8 \% \\ 3.4 & 3.6 \\ 0.0 & 1.2 \\ 0.0 & 1.6 \\ 0.0 & 0.5 \\ 1.1 & 0.3 \\ 0.0 & 0.0 \\ 100.0 & 100.0 \\ 89 & 1,252\end{array}$


TABLE A.2. Willingness of Homeowners to Adc. Energy-Saving Features to Their Homes and the Types of Heating System under Consideration (percent of resporidents)

\begin{tabular}{cccc} 
Willingness & & Pacific & Total \\
\cline { 2 - 2 } & & & \\
Quite willing & $55.1 \%$ & $61.6 \%$ \\
Somewhat willing & 37.1 & 31.6 \\
Not at all willing & 7.9 & 6.8 \\
Total & 100.0 & 100.0 \\
Number of respondents & & 89 & 1,246
\end{tabular}

Willingness to pay $\$ 1,200-1,500$ for storm windows or windows with thermal panes

$\begin{array}{lrr}\text { Quite willing } & 46.1 \% & 45.2 \% \\ \text { Somewhat willing } & 33.7 & 39.3 \\ \text { Not at all willing } & 20.2 & 15.5 \\ \text { Total } & 100.0 & 100.0 \\ \text { Number of respondents } & 89 & 1,243\end{array}$

Homeowners considering installation of another type of heating system

$\begin{array}{lcc}\text { Yes } & 25.9 \% & 19.2 \% \\ \text { No } & 74.1 & 80.8 \\ \text { Total } & 100.0 & 100.0 \\ \text { Number of Respondents } & 85 & 1,217\end{array}$

Homeowners converting or supplementing their heating systems

$\begin{array}{lcc}\text { Converting primary system } & 5.6 \% & 17.8 \% \\ \text { Adding supplemental system } & 94.4 & 82.2 \\ \text { Total } & 100.0 & 100.0\end{array}$

Type of heating system under consideration

$\begin{array}{lcc}\text { Electric resistance system } & 0.0 \% & 2.2 \% \\ \text { Electric heat pump } & 11.5 & 15.1 \\ \text { Gas-fueled furnace } & 0.0 & 9.2 \\ \text { Oil-fueled furnace } & 0.0 & 1.1 \\ \text { Liquid petroleum system } & 0.0 & 0.0 \\ & & \\ \text { Wood-burning system } & 69.2 & 51.5 \\ \text { Solar-powered system } & 11.5 & 12.9 \\ \text { Other } & 7.7 & 8.1 \\ \quad \text { Total } & 100.0 & 100.0 \\ \text { Number of respondents } & & \\ \end{array}$


5. Iitle: Fourth Annual Home-Shopper Survey: Buyer Preferences 1982

Author: Housing Magazine (McGraw-Hil1)

Date: December 1981

Sample: 2237 prospective homeowners who visited model homes in complexes of newly constructed homes

Relevant Findings:

1. $25 \%$ of those surveyed listed improved energy efficiency as a reason to buy a new home. The responses ranged from 15\% in Los Angeles to $38 \%$ in Kansas City. No Northwest cities were included in the survey.

2. On average, the following percentages of those surveyed would be willing to spend the amount shown for specific energy efficiency improvements in a newly constructed home:

\begin{tabular}{|c|c|c|}
\hline Item & $\begin{array}{l}\text { Est imated } \\
\text { Cost }(\$) \\
\end{array}$ & $\begin{array}{l}\% \text { Willing } \\
\text { to Spend }\end{array}$ \\
\hline Double pane windows & $5 D 0$ & 73 \\
\hline Upgraded insulation & 1500 & 87 \\
\hline Heat pump & 2000 & 39 \\
\hline Solar water heating & 2800 & 42 \\
\hline Solar water and space heating & 8000 & 32 \\
\hline
\end{tabular}

There was significant regional variation in the responses.

3. $45 \%$ of those surveyed were looking only at newly constructed homes; $55 \%$ were also considering existing homes. 
6. Title: National Homebuying Survey

Author: Economics and Research Division, National Association of Realtors, Chicago, Illinois.

Date: $\quad 1981$

Dbjective: Survey recent home buyers to give an understanding of the home buying and selling process.

Sample: 5200 individuals who had recently surchased homes, including 2,000 who had also recently sold a home. The survey was administered between March and May 1981 in 14 cities. The only Northwest city included was Seattle.

Relevant Findings:

The survey contains a variety of data including information on:

1. household composition

2. household income

3. number of prior homes

4. price range of past home v5. current home

5. whether move was local or long distance

6. type of home purchased by household, age, income and composition

7. reason for moving

8. energy considerations

9. median price by home type

10. use of Realtors 
Importance of home attributes related to energy:

Size of home

Type of heating used

Location closer to work

Energy efficiency of home

Design of home

Availability of public transport

Location closer to shopping
Very

Important

$39 \%$

$32 \%$

$32 \%$

$31 \%$

$30 \%$

$20 \%$

$18 \%$
Somewhat Important

40

41

31

41

42

23

38

Not

Important Total 21

$100 \%$

$27 \quad 100 \%$

$37 \quad 100 \%$

$28 \quad 100 \%$

$28 \quad 100 \%$

$57 \quad 100 \%$

$44 \quad 100 \%$

Stated reasons for purchasing the home:

\begin{tabular}{|c|c|c|c|}
\hline Reason & $\begin{array}{l}\text { Local } \\
\text { Movers }\end{array}$ & $\begin{array}{c}\text { Long Distance } \\
\text { Movers } \\
\end{array}$ & All Movers \\
\hline Tax advantage & $28 \%$ & $19 \%$ & $27 \%$ \\
\hline Rising home prices & 23 & 12 & 21 \\
\hline Larger home & 16 & 8 & 15 \\
\hline \multicolumn{4}{|l|}{ Prior neighborhood } \\
\hline dissatisfaction & 15 & 8 & 14 \\
\hline Employer change & 3 & 20 & 5 \\
\hline Job transfer & 2 & 20 & 5 \\
\hline Smaller home & 4 & 3 & 4 \\
\hline Condominium conversion & 1 & (a) & 1 \\
\hline \multicolumn{4}{|l|}{ Other } \\
\hline $\begin{array}{l}\text { Personal--divorce, health } \\
\text { death of spouse }\end{array}$ & 3 & 1 & 3 \\
\hline $\begin{array}{l}\text { Desire to own, pride of } \\
\text { ownersnip }\end{array}$ & 2 & 1 & 2 \\
\hline $\begin{array}{l}\text { Location near water, } \\
\text { relatives, etc. }\end{array}$ & 2 & 4 & 2 \\
\hline Marriage & 1 & 1 & 1 \\
\hline Retirement & (a) & 1 & (a) \\
\hline Total & $100 \%$ & $100 \%$ & $100 \%$ \\
\hline
\end{tabular}

(a) Less than $1 \%$. 
7. Title: None (Job No. 6463)

Author: Market Facts, Inc. Arlington, Virginia

Sponsor: U.S. Department of Energy

Date: $\quad$ September 1981

Dbjectives: The principal objective of this study was to gather information on the usefulness of home energy ratings to home purchasers. A secondary objective was to gain information on the role of energy efficiency considerations in the home purchase process.

Approach: The authors conducted their work in two phases. Phase one involved a literature review and a review of prior related studies conducted by Market Facts. Copies of their summary of studies that are related to this report are included as Titles $7 \mathrm{~A}, 7 \mathrm{~B}$, and $7 \mathrm{C}$. The authors al so conducted and summarized the result of focus groups held in Chicago and Richmond, Virginia.

Relevant Focus Group Findings:

1. Housing consumers assign greater value to homes with energy efficient features than to those without them.

2. Buyers of new homes appear more interested in energy efficiency than buyers of existing homes. The latter group is more interested in such features as location, established landscaping, and hardwood floors.

3. Focus group participants in Richmond would use energy efficiency as one of the five most important criteria in the home selection process. The Chicago participants ranked it lower. 
7A. Title: Study of Potential Home Buyers

Author: Market Facts, Ine.

Date: Fall 1980

Sample: 611 potential home buyers screened from consumer mail panel. National sample with approximately equal numbers from the South, Northeast, North Central and West.

Objectives: To describe potential home buyer awareness and attitudes toward passive solar energy and evaluate the potential of passive solar energy features.

Relevant Findings:

1. Reasons to buy another house:

$\begin{array}{lc}\text { Need more room } & 29 \% \\ \text { Want more room } & 29 \\ \text { Want a more energy efficient house } & 28 \\ \text { Job related } & 18 \\ \text { Likelihood of including energy saving features in new } \\ \text { house if offered at an extra cost. }\end{array}$
Scale: $3=$ very likely
2 = somewhat likely
$1=$ not at all likely

$\begin{array}{ll} & \frac{\text { Mean }}{2.7} \\ \text { Extra insulation } & 2.6 \\ \text { Automatic thermostat } & 2.6 \\ \text { Energy efficient appliances } & 2.5 \\ \text { Storm windows } & \end{array}$

3. Average cost/month for heating $\$ 88$. $37 \%$ of the respondents used actual bills to estimate their monthly heating bills, 50\% used rough estimate, $13 \%$ used a budgeted heating plan figure. 
4. Average cost/month for cooling $\$ 55$. $36 \%$ of respondents estimated cooling costs based on actual bills, $64 \%$ used a rough estimate.

5. Knowledge about how to save energy:

$26 \%$ of the respondents say they know a lot about how to save energy

$57 \%$ say they know some

$16 \%$ say they know a little

$21 \%$ say they know nothing

6. Sources used to get information about conserving energy in home:

Magazines

\% Respondents

Utility company

$87 \%$

Newspapers

76

Books

72

Government publications

68

63

7. $95 \%$ of respondents statec they needed reliable and accurate information about the initial cost of adding passive solar features to their home. $90 \%$ would need information on how much of their energy requirements passive solar could provide. 
78. Title: Perspective on Energy

Author: Market Facts, Inc.

Sponsor: Dow Chemical Co.

Date: $\quad$ September 1979

Sample: 1000 single-family homeowners throughout the country reached by telephone.

Objectives: To determine homeowners' attitudes about home energy costs and home energy efficiency.

Relevant Findings:

1. $63 \%$ of respondents agree that mortgage rates should be lower on energy efficient homes.

2. $83 \%$ of respondents recognize that well insulated, energy efficient homes will be worth more at resale than homes lacking such features.

3. Energy costs and energy efficiency were reported by homeowners as follows:

$94 \%$ are affected by rising energy costs

$94 \%$ are trying to reduce energy costs through conservation

$63 \%$ feel their home could be more energy efficient $41 \%$ are more concerned about energy cost than availability.

4. Past energy conservation activity (12 months prior to survey):

Lower winter thermostat

\% Respondents

)

Add weather stripping $79 \%$

4

Insulate water heater/lower temp. 55

Raise summer thermostat 51

Install stom windows/doors

Add attic insulation 39 31 
Replace major appliance with

energy efficient model

23

Add wall insulation 21

Add basement insulation 21

5. Desired energy saving features:

Attic insulation

\% Respondents

Wall insulation

$92 \%$

Weather stripping and caulking

90

Storm doors and windows

84

Basement insulation

84

70

6. When asked how much extra they would spend for an optional comprehensive insulation package that would save $25 \%$ on home heating and cooling costs, respondents said they would pay an average of $\$ 1362$.

7. Only $48 \%$ believe that new homes are more energy efficient than existing homes. 
7C. Title: Professional Builder's 1980 Consumer/Builder Survey on Housing

Author: Professional Builder Magazine

Date: Fall 1979 (See p. A.1 for 1981-1983 surveys)

Objectives: To describe the design features, motivations, products and amenities that today's potential home buyers are looking for.

Relevant Findings:

1. Housing preferences:

Detached single-family

$94.3 \%$

Attached single-family

Low-rise condominium

1.7

High-rise condominium

0.3

2. Buying motivations:

Investment

Inflation hedge

Privacy 31

Security 26

Raise family 26

Provides better way of life

3. Factors influencing buying decision:

Good appreciation

Size of house

Style and appearance

close to work

Warranties

10

Prestigious neighborhood

Near public transportation

4. Reasons why homeowners are in the buying market:

Location $36 \%$

Larger home 28

Profit on present home 
Newer home

Smaller home

Less maintenance

Energy conservation

Community features
10

9

8

6

2

5. $67 \%$ of potential homeowners want information about home operating costs with future cost estimates.

6. $57 \%$ would like displays showing energy conservation features of house.

7. $91 \%$ of buyers said they would pay $\$ 600$ for energy conservation packages.

8. Four out of the top five most popular options for newly constructed homes were energy saving features

$\%$ Respondents

Storm windows $64 \%$

Storm doors 60

Air-conditioning

45

Water saving showerheads 
8. Title: Energy and Housing: Consumer and Builder Perspectives

Editors: R. J. Burby

M. E. Marsden

University of North Carolina at Chapel Hill

Sponsor: North Carolina Energy Institute, North Carolina Department of Commerce

Date: Publication: November 1979

Survey Conducted: Fall 1978

Sample: Seventy-nine North Carolina households randomly chosen in proportion to county population.

Objective: Document current status of energy efficiency in new and existing housing in North Carolina.

Relevant Findings: Tables A.3 and A.4 are adapted from the text. 
TABLE A.3. Prospective Home Buyers' 'Interest in Energy Efficient Housing

indicator

Energy Saving Features Would Most Likely Look for in

Next Home

Insulation, storm windows, storm doors

Energy saving appliances

Wood stove/fireplace

Heat pump

Solar space or hot water heating

Design of house

Don't know

Total

Thought About Adding Solar Hot Water Heating

Yes

No

Total

$51 \%$

19

7

6

6

3

8

100

25

75

100

Willingness to Spend More to Save on Heating Bills

Spend $\$ 200$ More to Save $\$ 50$ per Year

Yes

90

No

Total

10

100

Spend $\$ 600$ More to Save $\$ 100$ per Year

Yes

No

Total

85

15

100

Spend $\$ 1200$ More for Heat Pump to Save One Third

on Heating Bills

Yes

80

No

Total $\underline{20}$

100 
TABLE A.4. Types of Households Most Likely to Demand Energy Efficient New Homes

\begin{tabular}{|c|c|c|c|c|}
\hline & Type of Household & $\begin{array}{l}\text { Features of } \\
\text { Next Home }\end{array}$ & $\begin{array}{l}\text { Save } \$ 100 \\
\text { Annually }\end{array}$ & $\begin{array}{c}\text { Hot Water } \\
\text { Heating } \\
\end{array}$ \\
\hline ' & Total Sample $\quad(N=79)$ & $87 \%$ & $85 \%$ & $25 \%$ \\
\hline & Location & & & \\
\hline$"$ & Mountains & 79 & 86 & 29 \\
\hline & Piedmont & 85 & 85 & 23 \\
\hline & Coastal Plain/Tidewater & 92 & 81 & 27 \\
\hline & Metropolitan area & 87 & 87 & 18 \\
\hline & Nonmetropolitan area & 85 & 81 & 32 \\
\hline & Urban & 83 & 83 & 27 \\
\hline & Rural & 95 & 85 & 20 \\
\hline & Current Residence & & & \\
\hline & Single-family-detached & 86 & 75 & 27 \\
\hline & Multiple-family & 89 & 100 & 28 \\
\hline & mod ine nomite & & & \\
\hline & Income & & & \\
\hline & Less than $\$ 10,000$ & 76 & 76 & 14 \\
\hline & $\$ 10,000-\$ 14,999$ & 95 & 86 & 23 \\
\hline & $\$ 15,000-\$ 24,999$ & 91 & 95 & 33 \\
\hline & $\$ 25,000$ or more & 80 & 73 & \\
\hline & Age & & & \\
\hline & Under 35 & 87 & 87 & 22 \\
\hline & $35-64$ & 82 & 77 & 32 \\
\hline & 75 or older & 100 & 67 & 33 \\
\hline & Education & & & \\
\hline 3 & High school or less & 83 & 85 & 20 \\
\hline & Some college or more & 91 & 82 & 32 \\
\hline a) & Race & & & \\
\hline & White & 86 & 83 & 24 \\
\hline & Nonwhite & 89 & 89 & 33 \\
\hline
\end{tabular}

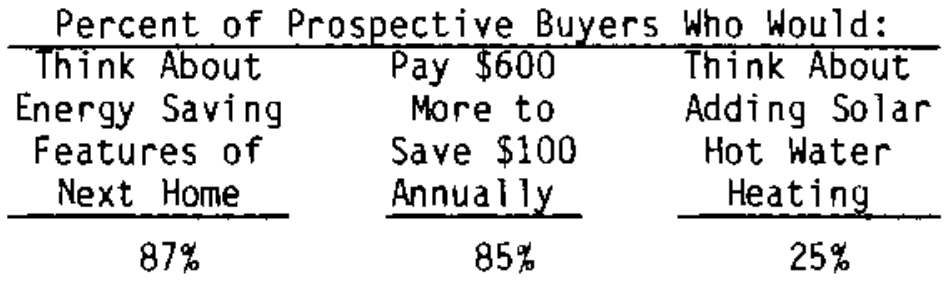


9. Iitle: Building and Occupant Characteristics as Determinants of Residential Energy Consumption

Report No.: PNL-4012

Authors: L. A. Nieves

A. L. Nieves

Pacific Northwest Laboratory, Richland, Washington

Sponsor: U.S. Department of Energy

Date: Publication: October 1981

Survey Conducted: February 1980

Sample: 35 households who had recently purchased newly constructed homes. 18 owners had purchased homes in Hermiston, Oregon, with energy efficiency features corresponding to code requirements (R-11 walls and R-22 ceiling insulation). 17 owners had purchased otherwise comparable homes in Hermiston or Kennewick, Washington, except that an energy package consisting of $R-19$ walls and R-38 ceilings was included.

Objectives: 1 . Observe actual energy consumption and compare to predicted consumption.

2. Investigate homeowners' conservation investments and home purchase decisions through a questionnaire.

Relevant Findings:

1. Surprisingly, energy consumption in the more energy efficient homes exceeded consumption in the less efficient homes. Possible reasons for the result include the small sample size, generally higher electricity prices for the less efficient home owners, higher household income for owners of more efficient homes, and the uncertain impact of wood heating. 
2. Factors reported to affect home purchase decision (listed in order of importance)

1. Purchase price

2. Neighborhood

3. Insulation

4. Floor plan

5. Quality of construction

6. Garage

7. Location

8. House size

9. Heating and cooling system

10. Number of rooms

11. Expected fuel bills

12. Size of lot

13. Exterior appearance

14. Sizes of rooms

15. Window placement

16. Style

17. Adequate natural lighting

18. Number and type of appliances

19. Effective cross ventilation

20. View.

3. The homeowners were also asked if they would be willing to spend an additional $\$ 600$ for a home to realize a $\$ 100$ annual saving in fuel costs. Forty-four percent of the sample answered yes, $50 \%$ indicated a willingness to spend more than $\$ 600$, and $6 \%$ had no response. 
10. Title: The Home Purchase Process: Measurement of Evaluative Criteria Through Pairwise Measures

Publication: Journal of the Academy of Marketing Science, Fall 1982, p. 359 .

Authors: $\quad$ J. B. Freiden

D. S. Bible

Approach: The authors interviewed 150 homeowners in a large midwestern city in 1977 who had recently purchased their home. Approximately $10 \%$ of the homes in the sample were newly constructed. The homeowners were asked to compare the relative importance of 17 housing and neighborhood attributes using the pairwise comparison technique.

Relevant findings:

Attribute

1. Safety from crime

2. Construction quality

3. Quality of schools

4. Living space

5. Storage space

6. Property values

7. Yard size

8. Traffic noise

9. Nearness to work

10. Nearby parks

11. Age of house

12. Neighborhood shopping quality

13. Neighbor backgrounds

14. Property taxes
Approximate Weighted Importance (0-4 Scale)

3.4

3.1

2.4

2.1

1.9

1.7

1.6

1.6

1.4

1.3

1.2

1.2

1.1

0.9 
15. Nearness to friends 0.7

16. Nearness to shopping 0.6

17. Bus service 0.0

Energy efficiency considerations were not explicitly included as an attribute, however they could be construed as being included in the construction quality attribute. 
11. Title: Joint Decisions in Home Purchasing: A Muddling Through Process Author: C. W. Park

Publication: Journal of Consumer Research, September 1982, p. 151. Sample: 48 couples who had recently purchased a home or who were actively searching. Only 15 couples were used to test Objective 2. All couples were in a Midwest university town and were interviewed in 1977.

Objectives: 1 . Test the conceptualization that:

a. A joint decision (in this case purchase of a home) by a husband and wife is a muddling through process characterized by limited knowledge and awareness of each spouse's decision strategies.

b. The spouses can reach an effective choice by relying on conflict avoiding heuristics.

2. Test mutual relative influence of spouses for 24 home purchase dimensions (attributes).

Relevant Findings:

1. The research supported the conceptualization in objective 1 above.

2. The relative influence for the 24 attributes are shown in Table A.5. The attribute of most interest to the present study, insulation, has significantly greater husband influence than wife influence. The greater husband influence is consistent with the finding in the Qualls dissertation (p. A.34). 
TABLE A.5. Couple's Reiative Influence Responses

Agreement (a)

Diınension

Husband Wife Sub Influence Influence

Age of home
Attractiveness
Central air conditioning
Basement
Builder's reputation
Fireplace
Fenced yard
Humidifier
Insulation
Interior design
Landscaping
Location
Neighborhood
Bedroom
Bathroom
Garage
Patio
Price
Recreation facilities
Resale value
Size of home
Style of home
Tax amount
Wet bar

2

1

4

9

1

4

3

0

11

0

3

3

2

3

3

10

0

17

1

13

1

2

7

0

\begin{abstract}
7
\end{abstract}
11

3

5

0

4

4

4

0

total

(9)

(12)

(7)

(1)

(8)

(7)

(0)
Don't

know

Response

16

10

18

13

3

1

1

4

18

2

10

0

1

1

10

6

1

8

13

19

18

26

17

20

7

16

3

7

9

10

10

0

(a) A dyad's response reveals an agreement about who influenced more on the dimension.

(b) A dyad's response reveals a disagreement about who influenced more on the dimension ( $i . e$. , each spouse indicated that $s /$ he influenced the other more).

(c) Either one or both of a dyad revealed a "don't know" response about who influenced more on the dimension. 
12. Title: A Study of Joint Decision Making Between Husbands and Wives in a Housing Purchase Decision

Author: W. J. Qualls

Doctor of Business Administration Dissertation

Indiana University

Date: $\quad 1982$

Sample: 108 couples

Relevant Findings:

1. For the housing decision attributes of floor plan, style, location, and optional built-ins, both husbands and wives believed that there should be approximately equal influence between them.

2. For the housing decision attributes of price, optional exterior, and optional energy saving features, wives perceived that these decisions should be made with joint and approximately equal husband and wife influence. Husbands, however, viewed these areas as principally their decision responsibility.

3. The author suggests that real estate marketing practitioners should concentrate their efforts for housing subdecisions on price, optional exterior, and energy saving features on the husband. Marketing efforts for the master suite, home style, floor plan, and optional built-in product features should be concentrated on the wife. 
13. Iitle: The Use of Home Energy Audits and Home Energy Rating Systems in the Home Selection Process

Author: Decision Research Corp. Lexington, Massachusetts

Sponsors: Energyworks, Inc.

Pacific Northwest Laboratory U.S. Department of Energy

Date: July 1982

Sample: Nineteen homeowners who participated in two focus groups in Lexington, Massachusetts, on June 16, 1982.

Dbjectives: The primary objective of the focus groups was to gather information on the use of home energy rating systems in the home selection process. A secondary objective was to gather information on the role of energy efficiency in the home selection process.

Publication: The results of the focus groups are summarized in Section 2.4 of A. D. Ackerman, et al., The Massachusetts Home Energy Rating System Project, PNL-4763, Pacific Northwest Laboratory, Richland, Washington, August 1983.

Relevant Findings: The focus group participants generally indicated that price and location were the most important criteria in the home selection process. Energy efficiency considerations were considered relevant, but not determining unless the projected cost to heat a home is exorbitant or the houses under consideration are otherwise equal. A major reason for this view was that participants believed that a desired home with poor energy efficiency could be effectively retrofitted with energy conservation features. 
14. Title: Conservation Characteristics Among Determinants of Residential Property value

Authors: M. Longstreth, A. R. Coveney, J. S. Bowers

Publication: Journal of Consumer Research, June 1984, p. 564.

Objective: Decompose housing prices using regression analysis into the implicit prices of the components of housing including features affecting energy use and actual use.

Sample: 615 homes in the Columbus, Ohio, SMSA. All homes were owner occupied, single-family, detached, previously owned and heated with natural gas. Sale price data was collected for the period 1973-1980. All prices are in 1980 dollars.

Relevant Findings:

Independent Variable

1. one extra inch of wall insulation

2. one extra inch of ceiling insulation

3. additional 115 ccf annual natural gas consumption

4. additional $150 \mathrm{sq}$. $\mathrm{ft}$. of living space

5. family room

6. garage

7. each additional bathroom

8. $1 \%$ increase in pupil/ teacher ratio

9. impact of 25 year old house vs. 10 year old
Effect on Sales Price of Two Otherwise Identical Houses

$\$ 528$

$\$ 508$

$\$ 2,991$

$\$ 2,347$

$\$ 2,792$

$\$ 4,350$

$(\$ 1,252)$

$(\$ 1,287)$ 
15. Title: Tenant-Paid Energy Costs in Multifamily Rental Housing: Effects on Energy Use, Owner Investment, and Market Value of Energy.

Author: Lou McClelland, University of Colorado

Publication No.: DOE/CS-20050-1

Date: December 1983.

Relevant Findings:

This report looks at a number of issues related to energy consumption in apartment units. One survey question addressed is relevant to the present study. The author surveyed 69 apartment managers in Atlanta, Georgia, in June 1982 regarding the level of interset of prospective tenants in the energy efficiency of apartment units. Seventy-six percent of the managers indicated that tenants almost always ask about energy costs, $18 \%$ indicated that tenants often ask about the costs, and on $1 y$ \% of the managers indicated that tenants ask about energy costs half of the time or less. For the Atlanta apartment rental market at least, the results suggest a high level of interest in energy cost and efficiency among prospective tenants. 
16. Title: Final Report on the Class C Passive Performance Evaluation Program

Report No.: MASEC-R-81-014

Author: Mid-American Solar Energy Complex

Minneapolis, Minnesota

Sponsor: U.S. Department of Energy

Date: September 1981

Sample: 80 Midwest owners of passive solar home

Objective: Gather information on attitudes and user acceptance from owners of passive solar homes.

Relevant Findings:

1. The owners are generally very satisfied with their home.

2. Savings on fuel cost was the principal reason for buying the home.

3. Books and magazines were the primary passive solar information sources.

4. Most owners felt that their home's passive solar features increased its market value. 


\section{DISTRIBUTION}

No. of

Copies

$1 \quad$ OFFSITE

30 T. 0liver

MS / KT

Bonneville Power Administration P.0. Box 3621

Portland, OR 97208

27 DOE Technical Information Center
ONSITE

DOE Richland Operations Office

H. E. Ransom

3D Pacific Northwest Laboratory

W. B. Ashton

3. M. Fang

P. L. Hendrickson (20)

R. G. Rivera

Publishing Coordination MA (2) Technical Information (5) 
it

$\bullet$ 